\title{
Eusebian Reading and Early Medieval Gospel Illumination
}

\begin{abstract}
This paper proposes that patterns of reading fundamental to the Eusebian apparatus also structure aspects of figural illumination in early medieval gospel books. Beginning with in-depth discussion of the St Augustine Gospels (Cambridge, Corpus Christi College, MS 286) and extending into several Carolingian and Anglo-Saxon examples, the essay explores the idea that Eusebian principles of textual segmentation, cross-reference, harmony, and diversity define a number of elaborate visual programmes-both within and beyond illuminated canon tables themselves. The resonance between Eusebian attitudes to text and the selected artists' approach to the visual setting of the gospels suggests a complex interplay in the manuscripts' programmes between transmitting the four evangelists' texts and representing the distinct entity of the gospel book itself.
\end{abstract}

Quite apart from the great exegetes' interest in the four evangelists' individual texts, the identity of the gospels as a plural unity was a subject of vivid importance to writers from Irenaeus to Jerome and Augustine-not to mention

This essay owes a great deal to scholarly community: some arguments were seeded in discussion; others could not have been developed without the generosity of colleagues near and far. Several essential thanks are due up front and others appear in the notes. A conversation with Benjamin Diego renovated the way I see the Augustine Gospels Passion narrative. I warmly thank Diego for allowing me to include his observation of structural resonance between gridded canon tables and the Passion image of CCC 286. In his 2016 Stanford University BA thesis, 'Where the Word Dwells: Architecture and “Architexture” in Insular Gospel Books, 600-900 CE', Diego emphasizes the integrated spatial and mensural qualities of gospel books as a theme staged by the canon tables. I thank Marcia Kupfer for her prompt to coordinate my ongoing work on early medieval narrative with consideration of canon tables; and I thank Bruno Reudenbach and Hanna Wimmer for the fruitful occasion of the Hamburg conference. I heartily thank keeper Anne McLaughlin for answering my questions about the codicology and offsets of CCC MS 286 before I was able to examine the manuscript, and for her kind permission to do so before the article went to press. I am indebted to Mildred Budny for sharing the working chart of the quire structure she prepared while authoring her 1997 catalogue, which was essential for thinking through the structure of the manuscript from Princeton. I thank Stefan Trinks for valuable bibliography; and Jaś Elsner, Christoph Winterer, Susanne Wittekind, and the volume's peer reviewer for clarifying remarks about the text.
Eusebius himself. Patristic scholars repeatedly considered the meaning(s) of diversity and consensus (or consensus in diversity) as they worked to define the scriptural canon. The development of a relatively standardized form for the gospel book evinces no weaker commitment in Late Antique and early medieval communities to arguing for concurrent coherence and individuality in the texts of the four evangelists. This argument proceeded by material and visual- as well as by verbal means. As is by now well established, the selection and subsequent exegesis of Matthew, Mark, Luke, and John's accounts as the Four Gospels is not to be taken for granted in the story of the early Church; nor is the gospels' ultimate identity as a written text. ${ }^{1}$ The very practice of copying the four gospels as a materially integral textual set constitutes a statement on the nature of the gospels in and of itself. The material definition of the gospel genre consists in crafting connective visual tissue for the four gospels that ranges from formulaic Incipit statements to a full set of author portraits to additional imagery. It also consists in furnishing connective verbal tissue such as a full set of prologues or Jerome's syncretic preface texts. The physical statement of diverse unity and development of a relatively standard set of accompanying texts to constitute a gospel book should be taken for granted no less than the establishment of the scriptural canon.

By the early Middle Ages, the Eusebian apparatus was indispensable to the gospel genre: it appears in manuscripts of widely varying provenance, on every grade of production. Significantly, the apparatus became an essential component of gospel manuscripts' architecture, regardless of whether the tables as copied in any given instance are in fact useable as Eusebius designed. ${ }^{2}$ The fact of including the apparatus in the first place marks a separate function from its actual utility as a concordance. As traditions of exegesis on the tables themselves also attest, the canons play a critical representational role wherever they appear. ${ }^{3}$ The Eusebian apparatus embod-

1 On the subject of the gospels' written form, see Larsen 2018. For recent addresses to the subject of gospel canon, see Watson and Parkhouse 2018.

2 See e.g. Netzer 1994b; on the consequent representational function of the apparatus: Reudenbach 2019.

3 On the exegesis of the canons, see esp. Mullins 2001; and O'Loughlin 2017. 
ies several arguments about the nature of the gospels. ${ }^{4}$ In turn, the canon tables' swift and lasting integration into the material tradition suggests an ongoing affirmation of the power in the tables' arguments to shape the representational qualities of gospel books.

In this paper I synthesize some working observations concerning how a conception of the gospels in the Eusebian tradition was elaborated and enforced by the visual design of illuminated gospel manuscripts in the Latin west. I cannot tell a stepwise narrative of development here, but I begin with a close look at what, by virtue of survival, must count as the beginning of this story-a book whose text, codicology, and visual programme all richly show the conceptual work needed to forge a book form that at once presents and represents the gospels. I then proceed to a more glancing treatment of a network of examples from various cultural contexts in the Carolingian and Anglo-Saxon spheres. These later cases suggest that characterization of the gospels in the Eusebian tradition remained a steady spine in the evolving imagination of the gospel book as a visual genre, even while bookmen and -women exercised creative muscle that varied expression of its themes.

My core premise is as follows. Eusebius pioneered and embodied in his canon tables a method of approach to the four gospels as texts. His approach constitutes a mode of reading the gospels that became essential to a mode of representation for the gospel book. There exists a set of visual-material approaches to the gospels shaped by what we might call Eusebian habits-these include segmentation, cross-reference, the crucial idea of unity in diversity, and a basic premise that the gospels exist in a series of balances. They equivocate between four and one, text and story, eyewitness account and scholarly recension. All this harmonizing plays out within a heightened consciousness of the codex medium, and how that medium can best represent the complex entity of the gospels.

The 'habits' listed above define the canon tables themselves; they also demonstrably undergird the global design of many illuminated gospel books. As they unfold in figural illumination, these principles for approaching the gospels may or may not be traceable to a particular interest in the canon tables per se in any specific case. Rather than arguing for the canon tables as a direct model for gospel book designers, I describe instances that betray a deeper intellectual reciprocity. In the following examples, elements of the design suggest that the kind of thinking about the four gospels embodied by the Eusebian canon tables was also important in the choices made by

4 On the argumentative nature of the tables, see i.a., O'Loughlin 2010; Pulliam 2017. artists when crafting visual programmes for particular gospel books. The canon tables, often characterized as an entranceway, state a theme of unity in diversity and a set of principles for thinking about the relationships between gospel narrative and the text of gospel books. In the cases I will describe, figural illumination elsewhere in gospel manuscripts sustains both this theme and these principles. In short: by the seventh century at least, ideas continuous with the Eusebian principles for reading the gospels enumerated above-segmentation, cross-reference, unity in diversity-became guiding principles for representing the Latin gospels such that the texts could be read in various ways, or such that they could stand as representative of their genre in liturgical or teaching situations. It follows that the central preoccupation of Latin gospel illumination in the early Middle Ages-which one might assume to be primarily the life of Christ, or his person-is the definition of the gospel book itself. This definition turns on the tenet that the gospel book-like the gospels-is a plural unity. Unlike the gospels themselves, however, the gospel book is as decisively defined by its apparatus as by its scriptural content. ${ }^{5}$

\section{The Augustine Gospels and the Eusebian habit}

The fragmentary sixth-century manuscript in Cambridge known as the St Augustine Gospels was made by people working hard to define what a Latin gospel book would be. ${ }^{6}$ The text combines Old Latin and Vulgate readings, along with pericope markings and abundant corrections, and the manuscript is the earliest known surviving Latin

5 I have been thinking through aspects of this theme in several recent studies based in different traditions of illumination. I will keep brief here the points that appear elsewhere in earlier versions; pending publication of a longer work in progress, I invite the reader to treat the present essay and the following studies as a set: Kitzinger 2017, Kitzinger 2018, and Kitzinger 2020. See also Jaś Elsner's contribution to this volume for the integration of prefatory matter into the gospel genre, and interplay between the structures of prefatory images and texts.

6 The Augustine Gospels is Cambridge, Corpus Christi College, MS 286. CCC 286 has been fully digitized and is available through Parker on the Web: https://parker.stanford.edu/parker/catalog/mk707wk3350 (last accessed 13/04/2020). In characterizing the Augustine Gospels as a 'working' book it is worth noting that the parchment throughout is not of high quality, varied in thickness and containing numerous holes, fills, stitches and thin membranes (including, strikingly, in the Arrest vignette on fol. 125r). The text is heavily corrected, and the original setting contains several spatial miscalculations (e.g. fol. 58v). 
gospel book to include an extensive figural programme. ${ }^{7}$ The intersection of that figural programme with the codicology of the manuscript suggests how much the role of illumination in a gospel book was still a work-in-progress when the manuscript was made: no quire structure containing illumination works in exactly the same way. ${ }^{8}$ Broadly speaking, the codicology at once indicates how integral the illuminated pages were to the conception of the complete manuscript, and how fluid the solutions were for fitting the paintings into their quires.

As is readily apparent, the Augustine Gospels is an essential witness to developing thought on how to present the gospels in codex form in the Latin west. The manuscript is likewise one of the most important witnesses to Late Antique ideas about how to think about the gospels as text. Its images are precious and informative, but the Augustine Gospels survives incomplete. Most glaringly in the context of this volume, the manuscript lacks the beginning to Matthew and the general prefatory material, including the Eusebian canon tables that likely stood as the first sustained visual element in the book. Despite the missing tables, I argue that the Eusebian revolution can still be felt in the extant components of the Augustine Gospels' figural programme. Perhaps paradoxically, the lack of canon tables in the manuscript permits recognition of how strongly the book's visual structure nevertheless accords with many of their principles.

The Augustine Gospels contains two painted pages (Figs 1 and 2). Both set the manuscript in conversation with figural forms developed for other media and other scales (a point developed further below). ${ }^{9}$ Both also operate according to paradigms fundamental to the Eusebian apparatus. For my argument here, the second image (fol. 129v) is the best place to begin (Fig. 2). This image depicts an enthroned Luke holding an open book, ensconced under

7 For a summary of figural illumination in the Late Antique biblical corpus: Lowden 1999, at 41-45 for CCC 286. Christopher De Hamel affiliates the Augustine Gospels with Gregory the Great's own Roman scriptorium on the basis of the text and observes that the inclusion of pictures is itself in line with Gregory's defense of images to Serenus of Marseilles (De Hamel 2017, 33-39). On the 'Roman' argument for including images and stressing Gregory's interpretation of specific gospel readings see also Henderson 1999, at 72; and Lewine 1974.

8 See Appendix for a chart and description of the varying structures in the quires of CCC 286 containing illumination. I have included these to supplement the numerical collations published in De Hamel 2017, 38 and Wormald 1954, 17 (noting broken conjunctions): it seems helpful to visualize how contents meet codicology in this case.

9 Convenient printed color reproductions of the two surviving illuminated pages appear, respectively, in: Binski and Panayotova 2005, cat. no. 1; and Breay and Story 2018, cat. no. 8. On the inter-media references, see notes 29 and 37. an arch where his bull symbol appears in the tympanum. The symbol's Sedulian verse adorns the architrave, and a small tree sprouts on either side of the tympanum. Below, Luke is flanked by two vertical rows of small vignettes, grouped in six discrete pairs subdivided in each box by a wavy line. The two sets are each framed by marbled columns. Care was taken both to align the image with the standard text rulings, and to provide additional light rulings to proportion the components correctly. ${ }^{10}$

This brief sketch already implies that the spirit of the composition is intimately related to the way the architectural frames of early canon tables introduce to the space of the gospel book forms also proper to monumental compositions. ${ }^{11} \mathrm{~A}$ brief glance between the Lucan image and a roughly contemporary example like the Abba Garima Gospels I. reveals how close many formal qualities in the Augustine Gospels' evangelist portrait come to those of an arched canon frame. ${ }^{12}$ The correspondence runs deeper, however, into the conceptual structures of the composition-not only in the Lucan image, but also in the repeated approach to the evangelists across the volume. Offsets from pages now missing confirm that Matthew, Mark, and John all originally had portrait frontispieces of the same type as Luke's (see Appendix). ${ }^{13}$

10 'Extra' rulings were executed, e.g. for the interior edge of the columns. The tympanum was compass-drawn.

11 The perspectival recession of the evangelist's niche enhances the composition's frequent comparison to sculpture; see note 29. On the architectural qualities of canon tables themselves, see esp. Reudenbach 2009; and Diego 2016 (as cited in Acknowledgments note). The (literal) codification of author portraits as components of authoritative gospel manuscripts is a subject that bears much further consideration in light of Matthew Larsen's recent work on the largely oral perception of the gospel tradition well before the earliest illuminated witnesses to it: Larsen 2018.

12 Good comparisons closer in cultural context appear in two fragmentary sixth-century Roman survivals: Vatican City, Biblioteca Apostolica Vaticana, MS Vat. lat. 3806; and British Library, Additional MS 5463 (both digitized: https://digi.vatlib.it/view/MSS_Vat.lat.3806 and http://www.bl.uk/manuscripts/Viewer.aspx?ref=add_ms_5463_ fs001r (last accessed 13/04/2020). The visual correspondence is especially close in the marbled pattern of the canon columns in these cases, which echo the Lucan columns and Passion frame in CCC 286. As Francis Wormald observed, framing arches and even evangelist symbols are portable among major junctures in gospel manuscripts: the precise type of Luke's symbol in the Augustine Gospels reappears in the tympanum above the beginning of the Lucan text in the early ninth-century Canterbury 'Royal Bible' (British Library, Royal MS 1 E VI, fol. 43r; see Wormald 1954, 8-9). Susanne Wittekind's essay in this volume similarly treats the fluid application of canon tables' signature forms across genres.

13 De Hamel 2017, 39; Budny 1997, 16 (noting offset to Mark on fol. 75r) and 50; Wormald 1954, 3-4. While Luke's portrait faces the beginning of the gospel text, as Matthew's and Mark's apparently did 
For copyright reasons, this picture is only available in the print version. To view a high-resolution digitisation of the manuscript, please visit the link https://parker.stanford.edu/parker/catalog/mk707wk3350

Fig. 1: Passion vignettes, Italy, sixth century. Cambridge, Corpus Christi College, MS 286, fol. 125r. Photo: The Parker Library, Corpus Christi College, Cambridge. 
For copyright reasons, this picture is only available in the print version. To view a high-resolution digitisation of the manuscript, please visit the link https://parker.stanford.edu/parker/catalog/mk707wk3350

Fig. 2: Evangelist Luke. Corpus Christi College, MS 286, fol. 129v. Photo: The Parker Library, Corpus Christi College, Cambridge. 
Tab. 1: Identification of the Lucan scenes, according to the gospel quotes chosen by the Anglo-Saxon captionist.

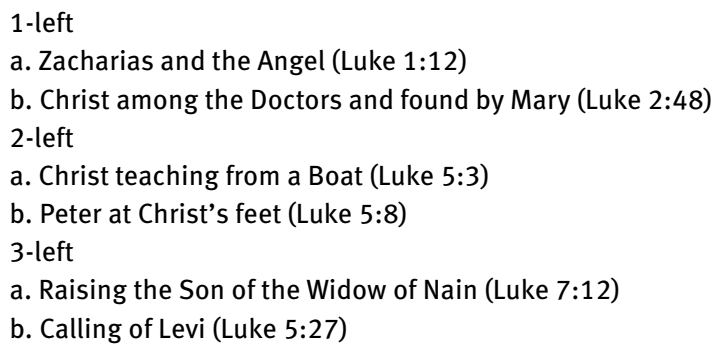

1-right

a. Christ and a Lawyer (Luke 10:25)

b. Christ Hailed by a Woman (Luke 11:27)

2-right

a. 'Foxes have Holes' (Luke 9:58)

b. Parable of the Fig Tree (Luke 13:7)

3-right

a. Miracle of the Dropsical Man (Luke 14:2)

b. Christ and Zacchaeus (Luke 19:2-4)
If the arched frame supports the crux of visual affinity between the Lucan portrait and a canon table, the intercolumnar vignettes carry the weight of conceptual continuity. The glosses added by an Anglo-Saxon captionist in the late seventh or early eighth century, which bear important witness to a reading of the image in conjunction with the gospel text, amplify the correspondence. ${ }^{14}$ Primarily gathering episodes drawn exclusively from the Lucan text, the series of scenes approximates a visual version of the Lucan portion of Canon X. ${ }^{15}$ Indeed, if one goes by the captionist's marginal tituli that fix an identity for the less definitive iconographies, only two of the twelve scenes have an exact parallel in other gospels: the Calling of Levi and the 'Foxes Have Holes' parable. ${ }^{16}$ The structure of the scenes runs as outlined in Table 1 (above), grouped according to the 'harder' division of six compartments and

as well, the traces of John's portrait face the evangelist's prologue. 14 In the following I work primarily with the captionist's interpretation of the scenes as evidence of an early medieval reading of the composition, but it must always be acknowledged that the captions might differ from the original intent of the design. On this point see esp. Lewine 1974.

15 In the Carolingian tradition of canon illumination that sets the evangelist symbols cavorting above the tables in canon-appropriate formation (e.g. the Soissons Gospels, Paris, BnF, MS lat. 8850; or British Library, Harley MS 2788), Luke's symbol appears alone (when possible) in the tympanum above Canon X.

16 All but three of the scriptural sections depicted in the vignettes, as identified by the captionist, are indeed classed by Eusebius in Canon X. The exceptions have parallels only in the Synoptic Gospels. Luke 5:27, the Calling of Levi, appears in Canon II (cf. Mark 2:14 and Matt. 9:9, where Levi and Matthew are conflated, cf. Matt. 10:3). Luke 10:25, the Lawyer's scene according to the Anglo-Saxon title, appears in Canon II (cf. Matt. 19:16-20 and Mark 10:17-20). Only Luke, however, specifically calls the man reminded to heed the Commandments a 'lawyer'. Luke 9:58, 'Foxes Have Holes,' appears in Canon V (cf. Matt. 8:20). However, if Carol Lewine is correct that the Anglo-Saxon captionist misread the Miracle of the Bent Woman (Luke 13:10-17)championed partly by virtue of the fact that this episode appears only in Luke-then all but at least two of the sections originally belonged to Canon X. As Lewine points out, the Calling of Levi composition might have purely Lucan alternatives as well (Lewine 1974). identified according to the line of scripture cited in the Anglo-Saxon caption.

It is clear that the Lucan selections distinguish the evangelist's account relative to the other three, in the same spirit as Canon X. The comparison to the Eusebian apparatus can be pushed somewhat further, though, as the composition of the vignettes in two parallel columns also invites the kind of comparison among them that is facilitated by the concordance tables across accounts. The patristic investigation I have completed by the time of writing does not suggest that these parallels correspond to specific exegetical traditions on Luke's gospel. ${ }^{17}$ It is possible nevertheless to suggest some ready categories by which the image's disposition of episodes, as read c.700, could create a web of reference internal to Luke. The first horizontal pair of vignettes (1a-left and 1a-right) calls on the theme of prefiguration: the coming of John the Forerunner is coupled with the lawyer Jesus advises to read the Law to know the essential precepts for eternal life. The next pair down (1b-left and 1b-right) features Christ's mother: Mary seeks her son in the Temple, and the woman who

17 Ambrose of Milan, for example, devotes at least passing attention to nearly all the selected episodes (even if not at the precise juncture flagged by the Anglo-Saxon commentator), as does Bede, but neither cross-references them among one another. The breadth of crossreferencing quotation across the gospels in works like Ambrose's Expositio Evangelii Secundum Lucam, however, reminds one of how much information we have lost in not being able to coordinate the Lucan selections with those of the missing portrait pages for Matthew, Mark, and John. A liturgical rather than an exegetical route seems more promising for pursuing the inter-columnar parallels; see Lewine 1974 for such an approach to the scenes' selection. All the pictured episodes have currency as pericopes: see Beissel 1907. However, Lucan passages marked out for reading in CCC 286 itself do not correspond to the pictured episodes (e.g. Luke 4, which is very heavily marked in the Augustine Gospels, fols 139r-140v, and does not figure in the vignettes at all; similarly Luke 19:46, fol. 189r). Thus, if the selection of scenes did correspond to local liturgical tradition, the connection was not overtly visually reinforced and we should consider how the painting operates as an independent system. 
hails him in Luke 11:27 blesses the womb that bore him. The entire row 2 speaks to a ministry theme: $2 \mathrm{a}$ and b-left represent two moments in the same longer scene of teaching, which ends with Jesus identifying Peter as the 'fisher of men'. 2a and b-right represent two parables, the raw stuff of Jesus' instruction, particularly in Luke. ${ }^{18}$ In the bottom set of boxes, 3a-left and 3a-right pair two types of miracle-a resurrection and a healing-while 3b-left and 3b-right depict the conversion of tax collectors (publicani) who both become important witnesses to the gospel events.

Suggesting such correspondence depends on the Anglo-Saxon's added marginal quotations that fix the identity of certain ambiguous compositions and definitively root all the scenes in Luke. Arguably, the commentator recognized the Eusebian-style possibilities in the composition and thought that the vignettes should facilitate comparison. Perhaps s/he made selective decisions in order to ensure the desired comparisons, such as choosing the identities of the Lawyer and the Woman for the two generalized scenes of encounter in box 1-right. ${ }^{19}$ The seventh-eighth-century reader may at least be said to have read the pairs of scenes him- or herself according to a logic that invites grouping and cross-reference, and labeled the segments accordingly.

Debate exists around certain identifications of the scenes because the sixth-century illuminator left a certain amount of ambiguity in the design from the beginning. If s/he was indeed working for a logic of correspondence across the two columns of images, it is concurrently worth noting that the reading of the Anglo-Saxon commentator (and possibly that of the initial artist) involved a malleability of the grid system. In order to achieve the desired set, in two instances the commentator broke the linear progression of Lucan chapters. To assign fixed Lucan quotations to the ambiguous scenes 3b-left ('Calling of Levi') and 2a-right ('Foxes have Holes'), the Anglo-Saxon returned to Chapter 5 after Chapter 7 (3a-left) and to Chapter 9 after

18 Lewine proposed that the logic of all four central scenes was conceived as 'Roman, petrine, and papal' (1974), 504. On the importance of Lucan parables in the Insular world, see Tilghman 2011, 302.

19 On the interpretive selection of comparisons involved in the Eusebian tradition, see Crawford 2015; and the contribution by Jeremiah Coogan to this volume. Budny suggests Minster-in-Thanet (Kent) as the earliest provenance for the manuscript, which affects the possible gender of the commentator. Budny also usefully observes that the titles might 'record a living oral tradition in England about the subjects and the cycle which derived from the Italian source for the book' (Budny 1997, 5-6). Henderson gave considerable weight to the intentional practice of captioning in the Insular world. He noted both the captionist's careful writing and his/her freedom with language in the Passion glossing, and posited that the Lucan identifications were driven by topical concerns (Henderson 1993-94).
Chapter 11 (1b-right). The remaining ten scenes run in strict chronological progression, preserving the flow of the Lucan text just as the canon tables do. ${ }^{20}$ The commentator's negotiation of chronology-and perhaps even the painter's employment of flexible iconography-relates to the processes of assessment and revision of the sections and their correspondence that Jeremiah Coogan explores in medieval modifications of the Eusebian tables themselves. Whether in number or in image, Eusebian thinking invites rumination on how the identified or depicted story intersects with gospel text. The painter left room to consider possible options; the captionist chose a reading from among them.

Creative chronological progression is also the hallmark of the image on fol. 125r (Fig. 1), a $3 \times 4$ grid with marbled frame that itemizes the Passion from the Entry to Jerusalem through the Carrying of the Cross. Painted on an unruled but integral leaf, the Passion is visually isolated in the manuscript between the end of Mark and the prologue to Luke, with a blank page to either side. ${ }^{21}$ Like the Lucan portrait, the Passion narrative did not originally operate alone in the programme as a whole: traces of another narrative grid appear on fol. 265v. ${ }^{22}$ The final image apparently would have faced the end of John's gospel. No evidence of another such narrative grid appears in Mark

20 On the 'itineraries' of Eusebius's system, see Coogan 2017. It is possible that the sixth-century painter made at least one of the chronological shuffles already. The single sheet British Library, Additional MS 37472 belongs to a group of now-scattered twelfth-century leaves painted for the Canterbury Eadwine Psalter (Cambridge, Trinity College, MS R.17.1). The whole group is profoundly in debt to Late Antique compositions of the precise type as the Augustine Gospels' Passion sequence. The verso side of the London leaf depicts the Foxes parable in a split field. The upper half shows an explicit representation of the parable's subject (foxes in holes) while the lower half shows Christ, a group of disciples, and a questioning man in a configuration related to that of CCC 286. On the twelfth-century group, see Wormald 1954, 12-13; and Budny 1997, 10. Wormald quotes James 1936-37, when positing that the Anglo-Saxon commentator had a complete, alternate version of the same Late Antique cycle to rely on, and that the twelfth-century painter had a similar version on hand to copy. Occam's razor might suggest that the tradition of visually clarifying the subject of the scene at Canterbury could equally well depend on the annotation of the Augustine Gospels itself. Henderson proposed that the 'Calling of Levi' scene might originally have been intended as one among several possible episodes in Luke 9:57-62, an identification that would have kept the slot 3b-left strictly chronological in the sixth century (Henderson 1993-94). Lewine's alternate identification of the 'Foxes' scene as Luke 13:10-17 does not solve the jagged order on the right.

21 In being integral to a regular gathering of eight, the Passion image is an outlier; see Appendix. The other surviving sites of illumination coincide with irregular quiring.

22 Budny 1997, 50. 
(although codicologically its inclusion is not impossible); all the relevant quires before Matthew are lost. One can only speculate as to the contents, narrative divisions, and placement of the lost material, but it seems reasonable to posit a full Christological cycle-likely beginning with the Infancy and ending with the Ascension (or even conceivably with Pentecost, as in the Rabbula Gospels). ${ }^{23}$

The conception of the Passion sequence is clearly related to that of the Lucan vignettes in its atomizing selection: episodes from the narrative were chosen, visually composed, and juxtaposed to fill the grid. However, the two pages represent an essential difference: fol. $129 \mathrm{v}$ is in quo Lucas proprie; fol. $125 \mathrm{r}$ is in quo quattuor, drawing across all four accounts (and without limitation to episodes recounted by each one of the evangelists, as in Canon I). ${ }^{24}$ If the Lucan vignettes offer a representative slice of the gospel as a unique text, the Passion showcases the story that binds the four gospels together. Put differently, if the Lucan image is thoroughly Eusebian in its approach to the gospel, the Passion image evinces an approach to the gospels more like Tatian or Sedulius's, deriving a single story from the four discrete texts.

That said, the Passion image is not devoid of Eusebian-style thinking. Similar to the Anglo-Saxon captions to Luke, several sequencing surprises in the Passion have led scholars to pursue the reasoning that resulted in the appearance of Lazarus in the second row, and the chron-

23 Wormald remarked that the choice of scenes before Luke 'seems to imply the necessity of at least two other similar pages, one coming earlier in the MS. and illustrating the birth and early life of Christ, the other coming later and completing the cycle of the Passion' (Wormald 1954, 11-12). Henderson agreed, referring to the Passion grid in the Eusebian language of 'concordance' and comparing the layout to the Quedlinburg Itala (Henderson 1999, 68-69). The imaginable permutations of contents and placement yield rather different roles for pictorial narrative in the manuscript as a whole. We face several equally interesting scenarios for the distribution. Since John's narrative was placed as a finispiece (which may be related to the inclusion of both Johannine prologues), grids before Matthew and after John may have functioned rather like interior covers. Although Budny terms it a 'tailpiece' to Mark, the Passion is well timed before Luke to reinforce the sacrifice-centered exegesis on his symbol, embodied here by the Sedulian verse. In this respect the image is aptly called a 'frontispiece' and, given the importance of the Passion as a unifying theme in the gospels, may have stood alone in this position without a balancing image before Mark. That said, it is by no means impossible that at least three full-page narrative images are missing. A fully balanced cycle may have given Ministry scenes to Mark, if Matthew had the Infancy. What is presently known of the codicology neither precludes nor mandates the presence of a narrative grid before Mark, especially if some painting was executed on missing singletons. In terms of global concept, I do think an original full narrative set likely and argue for it here.

24 Budny catalogues the scriptural references: Budny 1997, 16-36. ologically scrambled place of the Washing of the Feet. ${ }^{25}$ Regarding the latter, Mildred Budny remarked that the order of the scenes 'does not necessarily entail reading [... only...] in horizontal rows from top to bottom'. She observed that the configuration of episodes permits two different ways of reading, which correspond to a distinction in gospel texts. Moving from the Last Supper directly to the Agony in the Garden along the horizontal reflects the order of the Synoptic Gospels; moving from the Last Supper to the Washing along the vertical mimics the Gospel of John. ${ }^{26}$ By the same token, I would add that the Lazarus scene offers an alternate beginning to the image sequence if one looks to John: moving from Lazarus to the Entry into Jerusalem mirrors the progression from John 11 to John 12 (and appropriately anticipates Christ's own resurrection in the lead-in to the Passion). Following this rationale, the design of the Passion appears driven not only by a harmonizing story; it also includes a consciousness of diverse texts. The design preserves distinction within the gospel versions that together bear witness to sacred history. In this, again, the Passion design might be said to blend the counterpoint of canon tables with the synthesis of a Diatessaron. ${ }^{27}$ More thoroughly Eusebian in flavor is the notion that one might schematize the gospel story in a way that permits reading in multiple directions, or starting at various junctures.

It is impossible to know whether the Augustine Gospels originally began with a set of canon tables, and what form they took. The planned presence of a set does seem likely: the marginal sections are absent in parts of the manuscript, but generally speaking the bookmakers wove the Eusebian system through the text. Canon tables could have set the stage for dialogue with the later images in the Augustine Gospels in a variety of possible ways. Their simple presence would have proposed an approach to the gospels based on dynamics of selection and definition of the four accounts. Canon tables, of course, accomplish this wherever they appear. In the Augustine Gospels, the evangelist portraits-which all seem to have

25 Wormald obliquely considered a liturgical logic for Lazarus, and explained the Washing of the Feet by way of a model composition that combined the Last Supper and the Washing in two tiers, evinced later in Oxford, Bodleian Library, MS Douce 293, fol. 11r: Wormald 1954, 12. If a double vertical field for the Last Supper / Washing was a high design priority, that would have left the position occupied by Lazarus as a blank space needing logical occupation by an episode preceding the Entry but still related to the Passion.

26 Budny 1997, 5.

27 Crawford 2015 stresses the importance of Eusebius's maintaining the individuality of all four accounts, and his innovative solution to the Ammonian problem of making one dominant account the basis of the cross-reference. 
been designed on the same basic model-would have reiterated the principle in the body of the manuscript with particular force. Moreover, the tables' visual design might well have included forms that spoke directly to those of the Lucan architecture and/or the frame for the Passion. In a precise formal reciprocity remarked to me by Benjamin Diego, if partially or wholly gridded in their organization-a variant evident in the fourth-seventh-century papyrus fragment at the Metropolitan Museum of Art, the sixth-seventh-century 'Golden Canon Tables' in London, the canons of the Abba Garima III. Gospels, and surviving later in the Book of Kells-the canon tables would have literally anticipated the form that currently stages the single story tying the evangelists' accounts together across the manuscript (cf. Elsner, Fig. 29). ${ }^{28}$ Indeed, in his contribution to the present volume Jaś Elsner advances a broader comparison of the Passion grid form to Late Antique chapter summaries (such as the Vatican Virgil's).

In a related confluence of forms, the marbled framing of the narrative grid becomes notable both for its reference to monumental media, and for its connection to the Lucan portrait. This detail immediately echoes the visual language of the setting for Luke, which reflects that of both architectural canon tables and architectural sculpture itself. ${ }^{29}$ It seems that the artist sought a fusion between principles of reading and of monumental representation, defining the book simultaneously as material text and as a venue for images bound both to the gospel stories and to a wider world of Christian art.

In this light, the evocative particulars of the Lucan frontispieces that imply a Eusebian habit of mind become the tip of a proverbial iceberg of integrated design. Most importantly, the Eusebian assertion of diverse unity corresponds not only to the granular composition of the Passion grid, which incorporates all four gospel texts, but also to the physical distribution of a single visual narrative across at least two junctures in the manuscript. The entire programme was built to represent the same essen-

28 The Coptic example at the Metropolitan Museum of Art (New York), Inv.No. X.455 is digitized, as is British Library, Additional MS 5111/1, the 'Golden Canon Tables' (see note 62): https://www.metmu seum.org/art/collection/search/474440 (last accessed 13/04/2020).

29 I thank Elsner for reminding me that the format of the Augustine Luke, with its vignettes flanking a monumental central figure, exists in dialogue specifically with Mithraic altars; see Wormald 1954, 7, quoting Fritz Saxl in turn. Hans Holländer noted the same parallel and additionally invoked triumphal arches in his characterization of the image: Holländer 1969, 24. Henderson added the intercolumnar reliefs pictured on tombs such as that of the Haterii in the Vatican (second century), and compared the dynamic of large portrait and small scenes to that of monumental mosaics such as those of the fifth-century Aquilino Chapel at San Lorenzo, Milan: Henderson 1999, 69. tial principle that animates the canons, characterizing the gospel book as four distinct accounts stemming from one source. The in proprie compositions, likely originally provided for Matthew, Mark, and John and surviving in Luke, would have worked together with the extended grid narrative to assert the particularity of each gospel within their collective witness to a single essential story.

It is important conceptually as well as visually that the evangelists cannot stand alone. The idea of individual authorship is preserved-even decidedly emphasized-in the portraits and their frames, but in the illumination programme at large it is fundamentally intertwined with the notion of the four gospels as one textual, material entity that testifies to the major events of Jesus' life. The narrative cycle possibly began with the extant Passion, but I would propose that the absence of infancy scenes described only in Luke-particularly the Annunciation to Mary-among the Lucan vignettes selected for fol. 129v virtually guarantees that a missing grid narrative proximate to Matthew or Mark began with the Infancy, aligning the chronological structure of the Christological narrative with the codicological structure of the manuscript.

On this premise, the episodes represented as the work of one particular evangelist (as surviving at Luke) are represented both as crippled without the narrative that pulls across all four (whether originally fully depicted or not), and as continuous with that greater story. The relationship between the Lucan portrait scenes and the Passion grid is a case in point: the last scene in the Lucan frame, Zacchaeus up his sycamore tree, immediately precedes the Entry to Jerusalem (Luke 19:28-44), which leads the Passion sequence on fol. 125r. Indeed, the tree-climber was so closely identified with the Entry that early iconography made Zacchaeus a component of that scene. ${ }^{30}$ Even the design of the surviving Passion grid suggests interdependence between this image and other elements of the gospel book. Ending at the Carrying of the Cross, the sequence begs completion by the Crucifixion at least. How this completion was accomplished remains unknown, but at least four possibilities present themselves. Three scenarios involve a larger network of images: an independent, full-page image of the Crucifixion; the narrative after John commencing with the Crucifixion; or a Cross or Crucifixion on the original cover of the book, binding the

30 The tree-climber at the Entry, known from fourth-century sarcophagi on, is not always specifically identified as Zacchaeus. I thank Meseret Oldjira for notice that Zacchaeus is not only a frequent and named denizen of Ethiopian Entries to Jerusalem, but one fifteenth-century instance includes a man explicitly labeled Levi in the same image: New York, The Morgan Library \& Museum, MS M.828 (the Gospels of Zir Ganela), fol. 12r. On Zacchaeus in CCC 286 see Lewine 1974. 
whole gospel together in the unifying event. ${ }^{31}$ The fourth option emphasizes a deep interdependence of text and image-that is, no pictured Crucifixion at all.

In other words, the probable global design of the visual programme ensured that the manuscript represented the gospels not only as discrete tellings, but also as a set of texts whose whole is distinct from the sum of its parts, ripe for reading and interpretation. As if to tip a hat to this approach, the words written in the book held on Luke's knee are not his own. Fuit homo missus a Deo cui nomen erat Iohannes might commence like the 'second' beginning to Luke, Fuit in diebus Herodis (Luke 1:5), but in fact quotes John 1:6. ${ }^{32}$ The cross-reference strengthens the invocation of John the Baptist in the Annunciation to Zachariah, while reminding the reader that Luke's treatment of the Forerunner is just one among four. All this is to say that, in creating a visual structure for their gospel book-originally at a time when gospel illumination in any form was by no means a given-the bookmakers and annotators of the Augustine Gospels maintained consistent focus on how illumination could contribute to characterizing the gospels as written, materialized scriptureabove and beyond an individual manuscript's role as an agent of textual transmission.

31 A full-page Crucifixion image might have been a singleton, or conceivably intended for the verso of fol. 125, which is blank and not ruled for any additional content (unlike fol. 129v, which was both pricked and lightly ruled for two-column text). If a singleton, the possibilities for its placement multiply. Later examples such as the Franco-Saxon Gospels of François II (Paris, BnF, MS lat. 257) or Angers, Bibliothèque municipale, MS 24 evince a tradition of crucifixions placed in an isolated position before Matthew. See Kitzinger 2019, 160-175. A generous spacing of blank pages precisely comparable to that around the Passion cannot have been built around any of the known missing images (see Appendix). I thank Charles Barber for emphasizing the possibility of a cover cross in completing the programme.

32 Budny argues that the inscription is original, partly on the basis of matching inks within the image: Budny 1997, 4. Henderson 199394,247 , observes a contrast in planning between this inscription and the vignette captions. It is worth noting that modifications to the illuminated pages are in evidence: e.g. the brown ink trees added in the Betrayal, or the black touch-ups to the columns flanking Luke. The same ink used for writing in Luke's codex was used to define the book's left-hand verticals and tassles, after the first brown ink went down. While it remains difficult to date these phases, we can say at least that the Johannine text belongs to a second round of thinking about how to define the evangelist's image.

\section{Genre definition and the function of illumination}

John Lowden began his touchstone survey of scenic imagery in Christian biblical manuscripts up to the early seventh century with the elegant point that the words 'book' and 'books' are, respectively, the first and the last of the gospels. ${ }^{33}$ Having canvassed the evidence in the Greek, Syriac, and Latin traditions, maintaining an emphasis on the singularity of each manuscript, Lowden ended the essay with a hypothesis about the early purpose of 'biblical illumination' that is worth quoting in full:

I propose that the illustrated biblical manuscript was a response to a Christian demand for and love of sacred images that had been developing with increasing momentum through the fourth and fifth centuries. I think public art, in the form of the large and conspicuous cycles of biblical images that began to appear in churches around 400, must have changed attitudes. And I believe biblical manuscript illumination was a fifth- and sixth-century response to those changes. ${ }^{34}$

Lowden's observations inform a trenchant way of thinking about the function of illumination in a programme like the Augustine Gospels', particularly when his opening and closing remarks are taken together. As I have written elsewhere, I advocate that one useful way to define the purpose of manuscript painting-especially in the early medieval period, when so many genres are in development-is as a definition and presentation of the book-type at hand. ${ }^{35}$ As Lowden noted, the gospels have their identity as books inscribed as the alpha and omega of their texts. It is the function of all the textual-numerical apparatus scaffolding those texts in their material form-canon tables, marginal sections, prologues, liturgical reading lists, explanatory prefaces-to help define the gospels as books, composed and used within the Church. Illumination-figural or not-serves the same end.

Lowden's closing insight concerns how figural painting in late antique manuscripts works relative to the larger environment of Christian cult. He proposes that we weigh whether biblical illumination should be understood as a symptom of Christianity's transition, by the early seventh century, from 'a religion of the book' to 'a religion of the image'. ${ }^{36}$ Lowden points to a key interlock between the worlds of the monumental and the bookish in defining Christian spaces and objects. In this vein, the visual cues

33 Lowden 1999, 9.

34 Lowden 1999, 57-58.

35 See note 5, esp. Kitzinger 2018.

36 Lowden 1999, 58. 
allying the Augustine Gospels images with architectural sculpture and large-scale painting should be given special weight. They suggest that the book's designers imagined the illuminated gospel manuscript as a portable genre in dialogue with public space. ${ }^{37}$ This premise, in turn, suggests that a manuscript like the Augustine Gospels demonstrates how the vectors of 'book' and 'image' are difficult fully to separate in the sphere of Late Antique Christian manuscript painting. ${ }^{38}$

The Augustine Gospels turns this symbiosis between book and image toward a visual definition of the manuscript that is rooted simultaneously in its textual identity and its identity as Christian art. Critically, the textual identity of the gospel book includes the apparatus: a full gospel book testifies as much to scholarly traditions of writing, translation, and reading as it does to the life of Christ. The apparatus directly embodies Church traditions of reading and interpretation. The text of scripture at once presents the biblical past in its contents, and ecclesiastical works of editing and translation in its form. The form and content of the images contain a related duality. An image like the Augustine Gospels Passion is powerful in its co-option of an idiom still (apparently) primarily monumental in the sixth century: continuous visual narrative in a setting that evokes the physical and architectural. But this narrative is shaped by its context no less than a monumental programme would be. ${ }^{39}$ Its context-the form of the image and its place within the full visual-physical makeup of the Augustine Gospels-makes the life of Christ testify to the medium of its transmission as much as the individual pictured events. That medium is the gospels in their collated book form, four-in-one according to the Eusebian vision.

37 See note 29. With reference to the Passion grid, De Hamel invokes a type of free-standing, subdivided panel painting that no longer survives from the period (De Hamel 2017, 41-42). Henderson and Claus Michael Kauffmann both reference the panel paintings depicting the life of Christ brought by Benedict Biscop from Rome to England in the seventh century for installation on the walls at Wearmouth-Jarrow: Henderson 1999, 73; Kauffmann 2003, 4 n. 16. On the paintings as discrete panels, see Meyvaert 1979. Meyvaert defers the possibility of a ceiling placement for the panels, but in light of the scheme surviving from the twelfth century at Zillis it seems worth not banishing entirely from consideration. Henderson 1999, 68 also invokes opus sectile.

38 The nigh-obsessive focus on books in books in late antiquity and the early Middle Ages speaks to this point as well. On the representation of books within books, see the collected studies in Denoël, Poilpré and Shimahara 2018; esp. Denoël 2018.

39 Cf. Tronzo 2001; Lavin 1990. See Poilpré 2013 for attention to the Passion sequence as evocative of historic place and commemorative itinerary.
When considered in concert with its associates in Lowden's compendium-both other manuscripts and monumental programmes-another self-reflexive aspect of the Augustine Gospels' definition through visual programme becomes striking. That is the lack of reference to texts other than those of the gospels or their own apparatus. On balance, most of the other (earlier, Greek or Syriac) survivors in Lowden's corpus include cross-scriptural reference as part of their 'illustration' of the gospels, whether through the accompanying citation of text from the Hebrew scriptures, held up by figures of the prophets; or through the depiction of other characters, such as Moses and Aaron, alongside New Testament vignettes. ${ }^{40}$ Relative to the Eusebian-style web of internal reference represented by the Augustine Gospels, the presence of the Hebrew scripture in these cases attests to another mode of reading altogether: the typological. Even in its relatively small size $(245 \times 180$ $\mathrm{mm}$, supporting the book's famous portability), the Augustine Gospels was designed on a different model: to champion a self-contained representation of the gospels. The manuscript's contents, its makeup, and its mode of presentation all reinforce a conception of the gospel book as an independent entity. That entity is defined according to highly structured systems of reading and understanding.

In sum, as consonant with specifically Eusebian principles as the visual programme of the Augustine Gospels might be, the greater point is that the people who designed that programme shared the Eusebian project in a different sense. They found an innovative answer to an imperative to represent the gospels to a reader-viewer. That answer contains ideas familiar to those interested in Eusebius: principally, the simultaneous unity and diversity of the four gospels; and an approach to gospel content that oscillates between attention to text and attention to narrative, between a valuation of parts and integration of a whole. The Augustine Gospels designers expanded their representation beyond textual inclusion and organization to include the way illumination sits in the body of the manuscript. That is, they approached representation not only

40 The Rossano Gospels (Rossano, Museo dell'Archivescovado) and the Sinope Gospels (Paris, BnF, MS suppl. gr. 1286) take the first route; the Rabbula Gospels (Florence, Biblioteca Medicea Laurenziana, Plut. 1.56) takes the second. In evoking the way Christological narrative was handled in Late Antique monumental compositions-as far as we know-I am thinking especially of the surviving example of Santa Maria Maggiore and the lost cases of Old St Peter's and San Paolo fuori le Mura. Benedict Biscop's Roman panels also included a typological set. Denoël suggests that the shifting forms of the written word in the Carolingian 'Beast Canon Tables', along with the root of the symbols' own forms in Ezekiel, constitute a play on the relationship between the Old Testament and the New in this context as well: Denoël 2018, 493-496. 


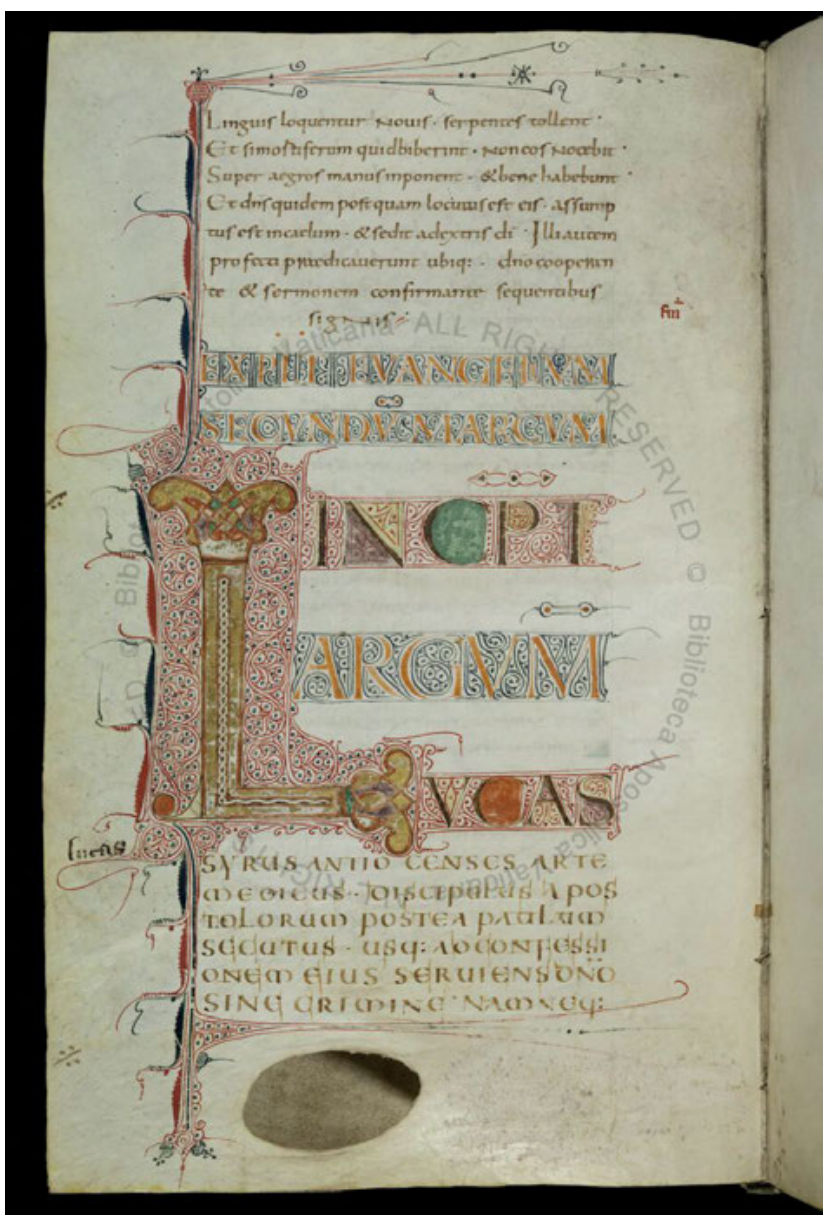

Fig. 3: Initial L (Lucan prologue), Saint-Bertin, ninth century. Vatican City, Biblioteca Apostolica Vaticana, MS Pal. lat. 47, fol. 81v. Photo: Biblioteca Apostolica Vaticana.

as a matter of picture (author portraits and scenic illustrations) but also as a matter of comprehensive composition, crafting a structure for the gospel manuscript that mirrors a way of understanding its genre.

In the specifics of how it combines its formal terms and its genre, the Augustine Gospels is a unicum among surviving early gospel books. In the spirit of that combination, though, it becomes part of a long story if we look to later traditions. I would like to complete this essay with two short sections that indicate how ideas established in the generation of the Augustine Gospels were still active in later traditions of gospel illumination. The first section calls for attention to the way the broader gospel apparatus was integrated into early medieval gospel book programmes, and how this affects the visual definition of the genre. The second section turns the tables to focus on the Eusebian canons themselves, and how their illumination could be made emblematic of the same project to represent the gospels visually-materially.

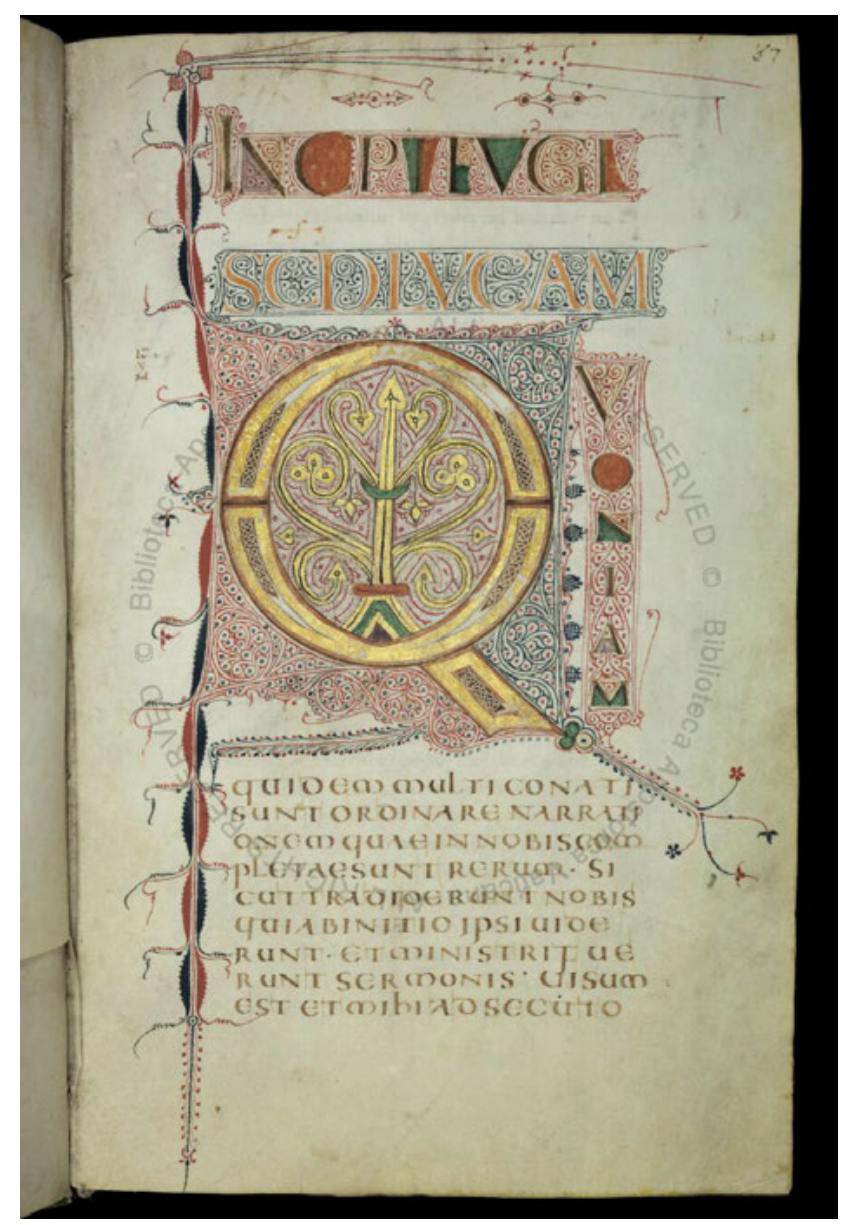

Fig. 4: Initial Q (Gospel of Luke). Vatican City, Biblioteca Apostolica Vaticana, MS Pal. lat. 47, fol. 87r. Photo: Biblioteca Apostolica Vaticana.

\section{Integrating apparatus}

Portraits of the writing evangelists far outnumber the $M a$ iestas, the Crucifixion, or other Christological images in surviving early medieval gospel programmes. It is a point perhaps so obvious as often to be overlooked that these portraits have two possible textual analogues in the contents of a full gospel book. One analogue is the authorial voice ascribed to the gospels themselves, most concretely evident at the beginning of Luke. It is in this spirit that Luke's image in the Augustine Gospels is regularly compared to Classical author portraits. ${ }^{41}$ The other textual analogue to the portraits appears in the prologues. The short texts introduce the evangelists as authors who wrote in particular places, for particular people. ${ }^{42}$ In various

41 E.g. Henderson 1999, 70; Holländer 1969, 35; Wormald 1954, 7. 42 Joshua O'Driscoll attends to the spectacular visual expression of this tradition in the Sainte-Aure Gospels: O’Driscoll 2019. 


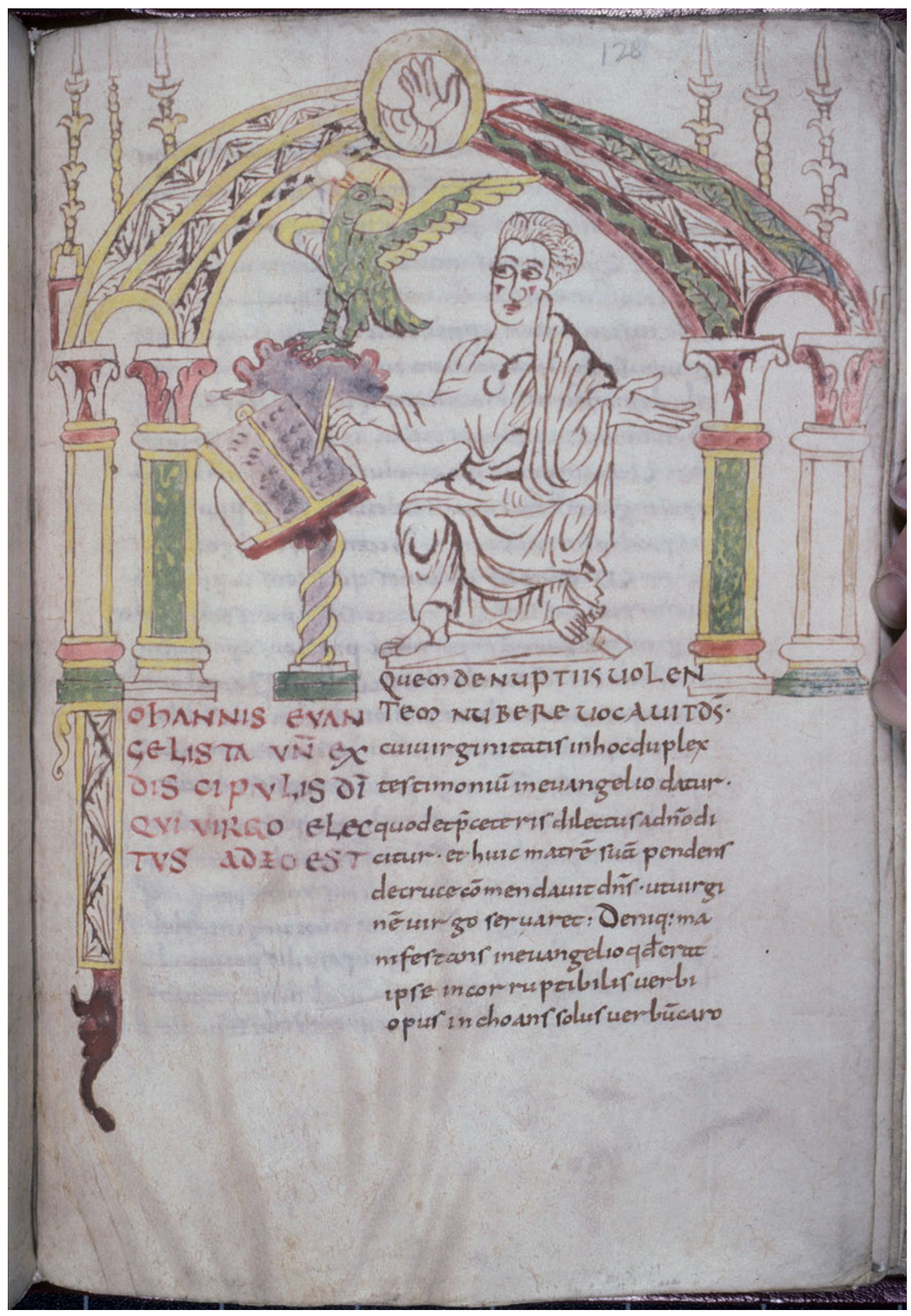

Fig. 5: Evangelist John, Loire Valley/Brittany, late $9^{\text {th }}$ century. Cambridge, Fitzwilliam Museum, MS 45-1980, fol. 128r. Photo: James Marrow, by kind permission. 


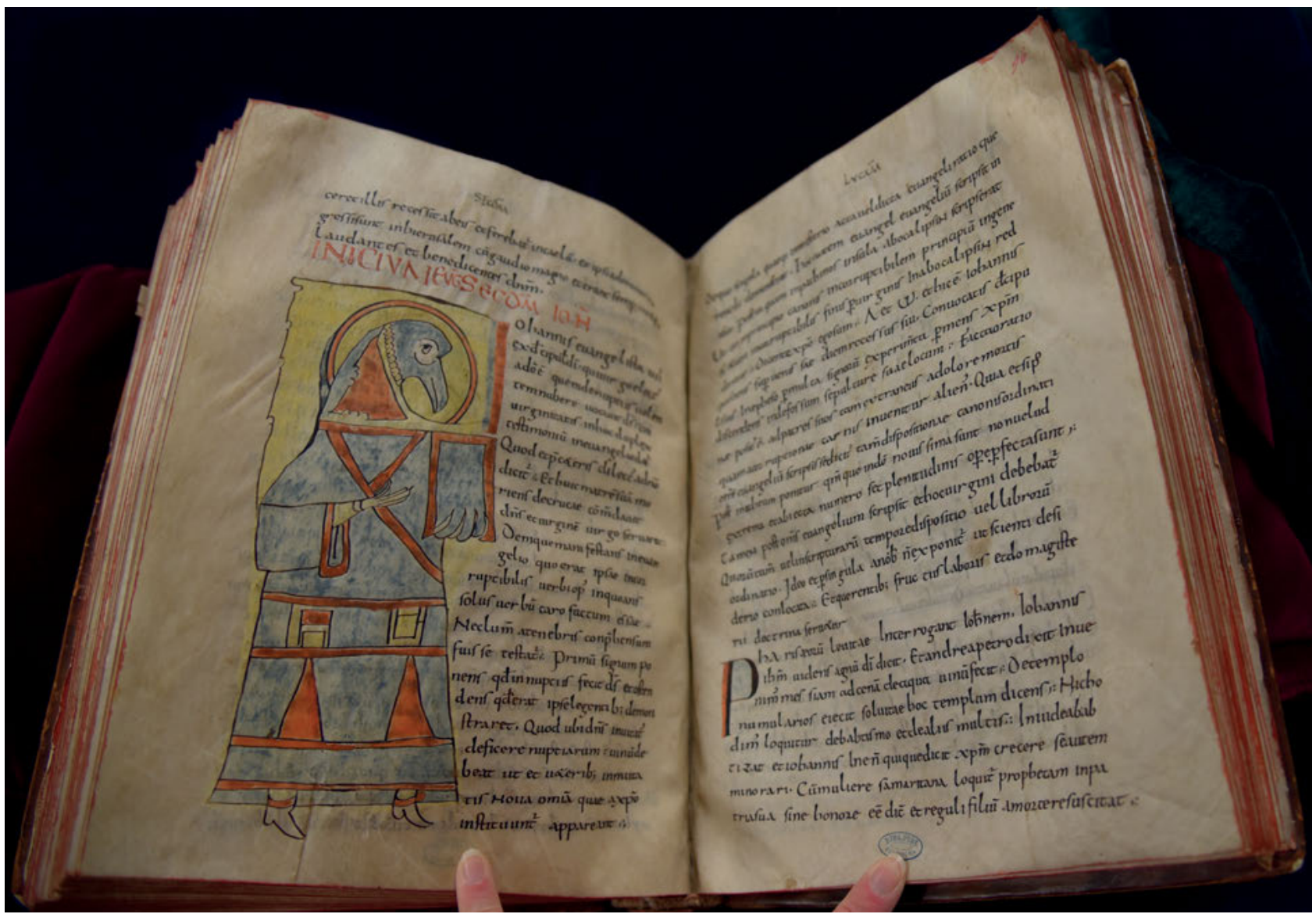

Fig. 6: Evangelist John, Brittany, late ninth/early tenth century. Boulogne-sur-Mer, Bibliothèque municipale, MS 8, fol. 95v. Photo: author, by permission of the Bibliothèque des Annonciades, Boulogne-sur-Mer.

instances, by various means, the prologues became a focus for illumination equal to, or sometimes greater than, the beginnings of the gospels themselves.

A case such as the Saint-Bertin gospel book held in the Vatican as MS Pal. lat. 47 includes no figural illumination but supports the case for the visual importance of the prologues. The initials for the prologue texts hardly pale in comparison to the major initials of the gospel beginnings, whether in size or elaboration (even disregarding the Gothic penwork additions to the pages) (Figs 3 and 4).43 To be sure, the prologue initials signal major divisions of the manuscript and as such their prominence is nothing more than practical. However, in the absence of evangelist images, the attention drawn to the prologues underscores

43 Mütherich et al. 2009, 314-318. The difference in size between the prologue and gospel initials is $6 \mathrm{~mm}(85 \mathrm{~mm}$ at fol. $81 \mathrm{v}$ and $91 \mathrm{~mm}$ at fol. 87r). The manuscript is fully digitized: https://digi.vatlib.it/view/ MSS_Pal.lat.47 (last accessed 13/04/2020). the ways in which these texts serve a parallel function to portraits, making the author human and present. ${ }^{44}$

Other dynamics emerge when author portraits are included, whether through placement or image composition. In the Augustine Gospels itself (barring rearrangement at a stage early enough to leave the offsets), John's portrait alone appeared not facing the first page of his gospels but in pendant to his prologue-also the only one of the surviving three to receive a separate incipit statement (fol. 205r). It might have been an accident of planning or a considered decision, but the result amplifies the role of the prologue, heralding the importance of the gospel authors alongside the weight of their texts. Precisely the same coupling of John's portrait with his prologue (in a manuscript that includes both versions of John's prologue, no less) occurs in Cambridge, Fitzwilliam Museum, MS 45-1980, a Breton or Loire gospel book of the late ninth or early tenth century (Fig. 5). Here, the artist's inclusion

44 On the relationship of evangelist portraits to the act of reading, see Willson 2020. 
of the candles also seems to refer to John's status as the author of Revelation, indicating the place of the gospels in a textual world that extends beyond the book's borders. ${ }^{45}$ At the turn to the tenth century, the Breton artist of Boulogne-sur-Mer, Bibliothèque municipale, MS 8 adopted a related attitude. This artist coupled Matthew, Mark, and John's figures closely to the text of their prologues with clear intentionality, creating a balanced equation and flow between the evangelist figures and the words of their introductions (Luke's portrait is rendered separately in this manuscript, framed in a figure-eight mandorla and facing his prologue across the opening) (Fig. 6). ${ }^{46}$ At the opposite end of the production scale, grounding the 'Court School' tradition, the artists of the Lorsch Gospels both oriented the evangelist portraits to the prologues and devoted great extra imaginative energy to the prologue of Matthew, depicting his gallery of Christ's ancestors above the text in a composition unprecedented $c .800 .{ }^{47}$ Similarly, Robert Walker argued that the scenic vignettes complementing the author portraits and contextualizing the beginning of Mark, Luke, and John's texts in the contemporary Soissons Gospels are best understood as episodes spotlighted in the prologues, not as selections with a particular Carolingian logic drawn directly from the gospel texts per se..$^{48}$ All these examples showcase the prologues as concentrated sites for illumination. Almost regardless of pictorial subject, the choice of the prologues as a prime location for painting communicates their centrality to the project of an elaborate gospel book's programme.

In ninth-century Tours, not only the prologues themselves but even their incipit statements-the apparatus to the apparatus-were occasionally afforded imaginative attention (Fig. 7). I have previously discussed cases that adopt the visual language of a Maiestas for the prologue and/or gospel incipits, so will only invoke them here. ${ }^{49}$ Easily the most complex of the illuminated Touronian incipits is that for Matthew's gospel text in the Prüm

45 Wormald 1977. A tantalizing echo of another compositional idea in the Augustine Gospels survives in Fitzwilliam 45-1980: this is the only known Frankish gospel book to thread a continuous visual Passion narrative through the four accounts. The form of this narrative (textually integrated single scenes) is distinctly different from that of the Augustine Gospels, but the idea to use the body of the gospel book to tell one story is familiar. I am preparing a separate study of this manuscript; at present, also for fuller discussion of Boulogne 8, see Kitzinger 2018.

46 Further on this case, see Kitzinger 2013, 36-38.

47 Alba Iulia, Biblioteca Batthyáneum, p. 27.

48 Paris, BnF, MS lat. 8850; see Walker 1948 and now Dombrowski 2019 on Jerome's preface. The manuscript is fully digitized: https:// gallica.bnf.fr/ark:/12148/btv1b8452550p (last accessed 13/04/2020). 49 Kitzinger 2017.
Gospels (Berlin, Staatsbibliothek, MS Theol. lat. fol. 733), which draws on different iconography (Fig. 8). Here, the lines of display capitals are interspersed with delicate scenes in silhouette. Above unfolds a sequence beginning with Joseph and Mary's arrival in Bethlehem, proceeding to the Nativity, and ending the line with the Annunciation to the Shepherds. The Presentation in the Temple appears below. The precise details of this composition are a subject for another discussion; the key point in this context concerns the combination of the narrative's subject and its position in the manuscript.

Like many Carolingian gospel books, the portrait of Matthew in the Prüm Gospels quotes the Sedulian verse on the evangelist that justifies his symbol. Since Matthew's gospel begins with the genealogy of Christ, his symbol is the man or angel, and his account was often associated particularly with the Incarnation. ${ }^{50}$ Accordingly, to depict an infancy sequence as the preface to Matthew seems only an appropriate match of subject and context. To stage a narrative sequence at Matthew, moreover, seems also an appropriate match of context and pictorial mode: the Incarnation, after all, is the essential predicate for the story of Jesus, and thus well represented by a vivid narrative image. From a textual point of view, however, the sequence is a mismatch-just as an Infancy sequence early in the Augustine Gospels would have been. The selected episodes do not occur in Matthew's text; in fact, they all appear only in Luke. In this, the Prüm Gospels exemplifies an even more extreme act of cross-gospel synthesis than does the Augustine Gospels' Passion image. The importation of Lucan material to the beginning of Matthew thoroughly divorces text from story in order to do work of representation-both for Matthew in his leading position, and for the gospel book as a whole. Painting serves not the illustration of a text but a characterization of the book at hand.

Flexibility in pairing text and image encapsulates the premise that the gospels and the gospel book (illuminated or not) are distinct entities. The illuminated gospel book, in particular, elaborates on its status as a material vehicle for the gospels that includes apparatus-in which category I would count complex decoration itself. As posited for the Augustine Gospels, gospel apparatus proposes a way of reading. That way of reading might be cross-referential and driven by text, like the canon tables; it might be contextualized in light of authorship, like the prologues; it might be communicative of an interpretive standpoint on the textual collection, like Jerome's Plures fuisse.

Speaking of which, a discussion of apparatus visually prominent in gospel programmes would, of course, not

50 See, e.g. O’Reilly 1998. 


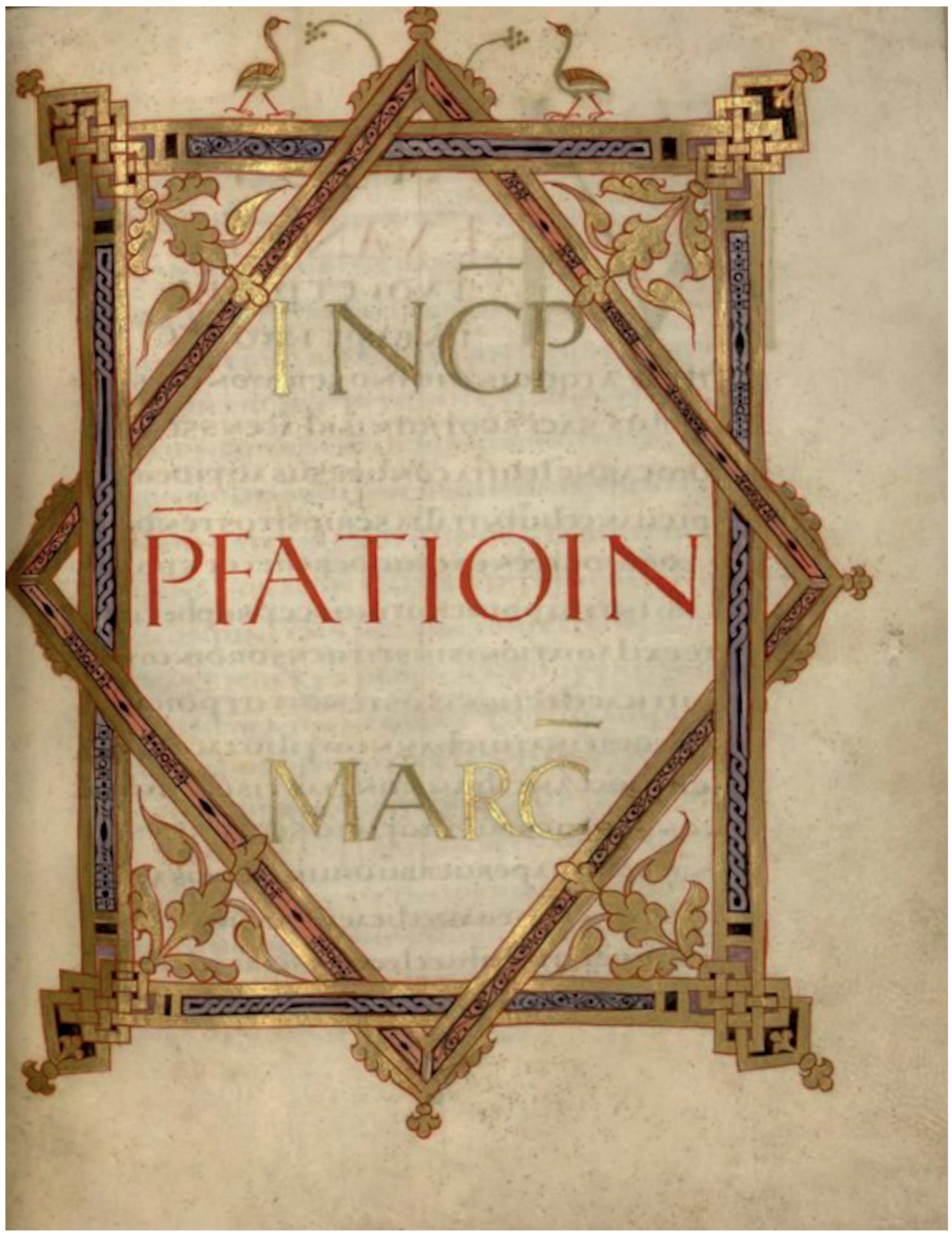

Fig. 7: Prologue to Mark, Tours, 844-51. Laon, Bibliothèque municipale, MS 63, fol. 83r. Photo: Bibliothèque Suzanne Martinet, Laon. 


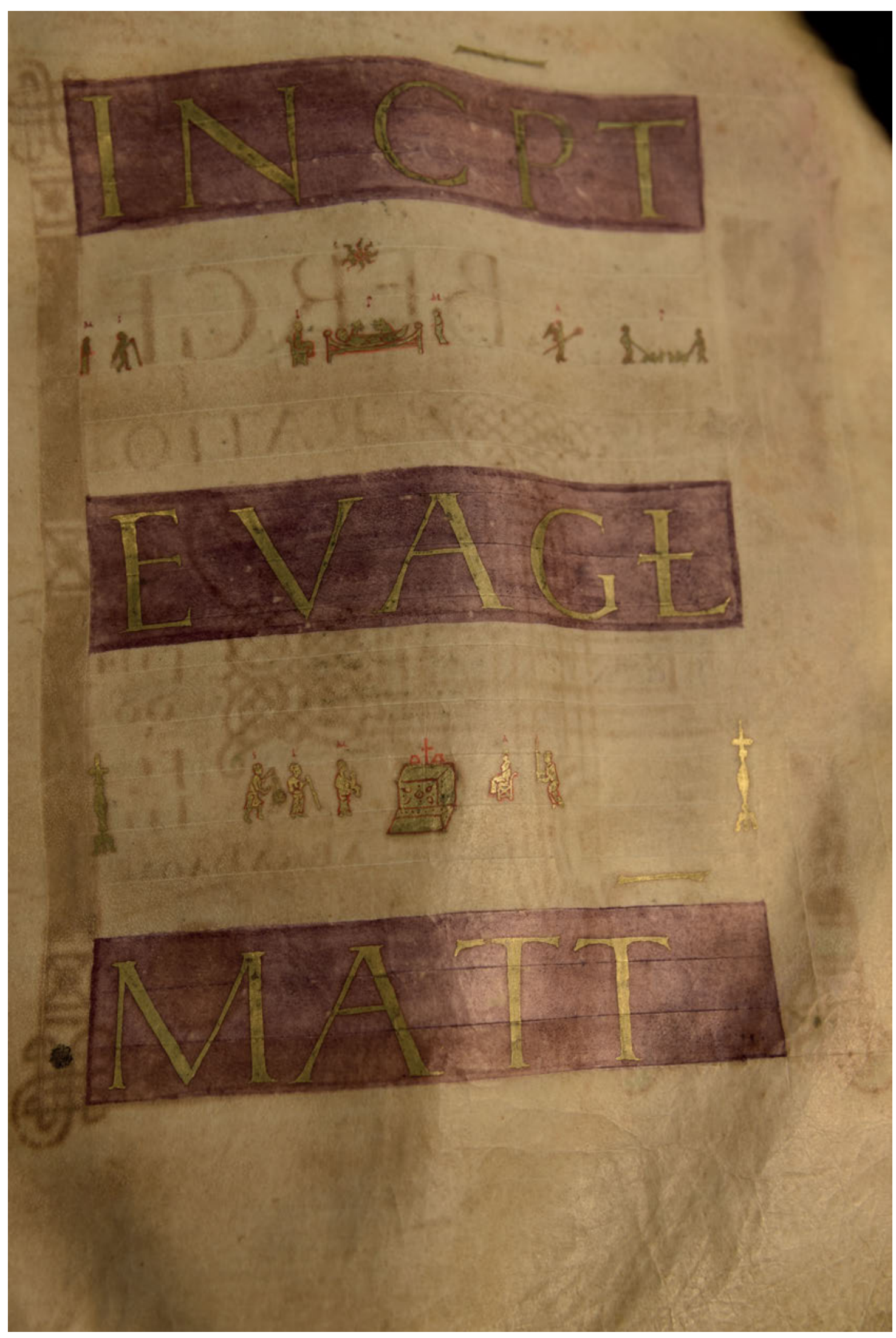

Fig. 8: Incipit to Matthew, Tours, 844-51. Berlin, Staatsbibliothek Preußischer Kulturbesitz, MS Theol. lat. fol. 733, fol. 23r. Photo: author, by kind permission of the Staatsbibliothek zu Berlin. 
be complete without mentioning the Maiestas domini and the evangelist symbols themselves. The Maiestas is a theologically sophisticated image type that well reflects the blend of human and divine in Christ's person, which one could easily describe as the unifying theme represented in all four gospels. As such, it might seem that the inclusion of a Maiestas in a gospel programme has more to do with exegesis than with text itself, more to do with theology than with reading. However, the Maiestas is not an image without textual ties, especially in a gospel context. The text most often implicated in the image type's development as part of illuminated book vocabulary is the Plures fuisse-which also replicates patristic exegesis on the identification of the four symbols throughout the corpus of medieval gospel manuscripts. ${ }^{51}$ That same text is associated with one of the most surprising, imaginative compositions in the Carolingian gospel repertoire: the edifice with the adoration of the Lamb and the symbols of the four evangelists that faces Jerome's preface across the first opening in the Soissons Gospels (fols $1 \mathrm{v}-2 \mathrm{r}$ ). All this is to underscore that the patristic apparatus surrounding the gospel texts played as defining a role visually as it does textually when early medieval bookmakers sought to couch scripture in the form of a gospel manuscript. The prominence of the apparatus defines the gospel book as a genre representative not of unmediated scripture, but of the evangelists' accounts conceived as texts within ecclesiastic traditions of scholarly practice. ${ }^{52}$

\section{Figuration and the Canon Tables}

The gospel apparatus is so much the focus of the Soissons Gospels' visual programme that the canon tables themselves are introduced by their own frontispiece: the prominent Fountain of Life that visually states the principle of the gospels' simultaneous distinction and common source (fol. $6 \mathrm{v}$ ). ${ }^{53}$ The makers of this manuscript (along

51 On the Plures fuisse and the evangelist symbols, see Denoël 2018, 493-494. Recently on the textual associations of the Maiestas: Darby 2017.

52 Ritual practice, of course, is an important component of representation in many gospel books; the inclusion of reading lists at the back of a gospel manuscript often balances that of the canon tables to the front. Functional or not, the Capitulare evangeliorum represents the gospels' imbrication in liturgy-just as the canons represent traditions of exegesis and reading. On liturgical representation in the gospel tradition, see, e.g. Farr 1997.

53 Underwood 1950. Variations on an inscription that states the single common source of the four streams appear frequently in the Touronian tradition. with other splendid witnesses like the Carolingian Harley Golden Gospels and the Insular Book of Kells) then followed through in spectacular fashion on the idea of representing the Eusebian premise of diverse unity throughout the tables. They implemented the so-called Beast Canon Tables, depicting the evangelist symbols cavorting in the proper configuration for each given canon. ${ }^{54}$ As the symbols jointly handle the scrolls that announce the canon numbers, the playful verve of these compositions keeps the idea of inspired authorship at the visual fore along with the idea of commonality across texts.

The opening comprising Canons V-VIII (fols 10v-11r) in Soissons marks a break in the established pattern of the tympana, and it deserves some attention here (Fig. 9). Canon V occupies the verso side, comparing Matthew and Luke. In the tympanum above, instead of the two symbols alone, a standing Christ appears in a starry blue roundel supported by two winged figures, who combine features of standard-issue angels with those of the canon-appropriate evangelists. Canons VI-VIII occupy the recto side, comparing, respectively, Matthew and Mark, Matthew and John, Luke and Mark. The tympanum reprises the Fountain of Life, with all four symbols gathered around it.

Paul Underwood proposed a nuanced reading of these compositions, which are startling both in the established corpus of canon decoration and in the established logic of Soissons' own set. Underwood based his interpretation first on the immediate juxtaposition of images and canon sections, and second on the pair of pages that build the whole opening. ${ }^{55}$ He argued that the way to understand the appearance of Christ and the Fountain in this opening was to seek 'the contiguous textual material to which these illustrations of the Canon Tables refer'. Underwood took that textual material to be the top line of Eusebian sections in the tables below. With this logic, Underwood identified the first parallel sections below the Fountain of Life to refer to Baptism (Matt. 3:4-6 and Mark 1:4-7); and those below Christ to refer to Christ Immanuel. He then posited the importance of recognizing a causal connection between the two apposite images: 'an analogy is set up between the significance of the coming of Immanuel and the significance of the baptismal font'..$^{56}$

In his essay as a whole, Underwood was concerned to excavate the centrality of baptism to the idea of gospel

54 Netzer $1994 a$.

55 Underwood 1950, 69-70.

56 Underwood connects Matthew, Section III also to the Fountain of Life image in the Godescalc Lectionary, by way of that image's inscription (Paris, BnF, MS nouv. acq. lat. 1203, fol. 3v). He further parallels his argument about an equation between the Virgin Birth and Baptism's rebirth in Godescalc's manuscript to the subjects of the Soissons canon opening. 
harmony, and his explanation of fols $10 \mathrm{v}-11 \mathrm{r}$ is part of that venture. In our context, the more pressing aspect of his reading is the recognition that the canon tables themselves become the subject of major illumination in the Soissons Gospels, and that their representation plays out on a structural level. Identifying the canons as a subject occurs first in the tables' Fountain frontispiece, but Underwood's reading of fols $10 \mathrm{v}-11 \mathrm{r}$ rests on the subtler premise that the Soissons artists took the sections themselves and their apposition as the subject of a visual gloss. In other words, the painters recognized that the way the codex form presents facing tables is ideal for constructing a theologically rich figural equation. In this, the canons become part and parcel of the same discussion begun above concerning the prologues and preface texts. The weight of illumination falls not on the text of the gospels themselves, but on the elements that frame them as part of a gospel book.

As such, the subject of gospel illumination in the Soissons Gospels becomes as much how we read the gospels in manuscript form as it is the historical or theological contents of the texts. I will return momentarily to the theme of juxtaposition, but first would like to observe that one need not even focus on Underwood's iconographies of baptism and Incarnation to argue for meaning in the pattern-breaking opening of the Soissons canons. Underwood's idea that the Soissons artists attended to the textual contents corresponding to the topmost sections and translated their focus into an exegetical image has a more pedestrian counterpart: the simple point that the combination of Canons VI-VIII, all concentrated on fol. 11r, represents the last moment in the canon tables when all four evangelists are accounted for (Fig. 9, right). As such, reprising the 'harmony' image in a more explicit form than the initial full-page Fountain would seem justified even within the visual logic of the 'Beast Canon Tables' alone, pressing home the point about unity before the full divergence begins.

That Canons VI-VIII all occur on the same page is itself not inevitable, but evinces considerations of space and distribution..$^{57}$ The painter was attentive in other respects to the possibilities opened by the decidedly cramped disposition of the short Canons VII and VIII, which ensures the presence of all the evangelists on the same page and

57 The distribution might have been worked out with an eye to completing the canon tables within one quire: Quire 2 ends with the final table on fol. 12v; Matthew's prologue begins the next quire on fol. 13r. Quire 2 (fols 5-12) comprises all the canon tables, preceded by the end of the Novum opus, whose continual text began in the first, half-length quire containing the Fountain of Life and the Hieronyman prefaces (fols 1-4). See Koehler 1958, 70. The same visual configuration of Canons V-VIII occurs in the Harley Gospels. renders it ripe for reiterating the theme of gospel harmony. On fol.11r, the painter introduced additional delicate roundels with the evangelist symbols, carefully labeled, on top of the third and fourth painted column shafts from the left. ${ }^{58}$ On the one hand, these reiterations of the symbols serve a clear function: the upper two confirm the evangelists compared in Canon VII (Matthew and John); the lower two confirm those compared in Canon VIII (Luke and Mark). On the other hand, I hold it significant that these little symbols display their own rationale relative to the configurations that define most of the tympanum images. Overleaf on fol. 11v, for instance, Canon IX compares Luke and John in the first two columns, while Canon X presents Matthew alone in the second two columns (Fig. 10). In the tympanum, Luke and John relate strictly to one another on the left side. Matthew faces away from them on the right to clarify that Canon X proceeds below him. In other words, the lateral composition of the symbols is keyed precisely to the legibility of the page as a whole, with the evangelists' bodies tuned to their proper columns. To remain consistent with this precedent, in the small additional symbol roundels either John and Mark should face right toward their sections in their current places, or they should be placed in the outermost painted column in order to face left. Either option would better clarify where their sections lie. In view of the fact that no rubric inscriptions state the contents of the two rightmost columns, such clarification would, in fact, be most welcome. However, it seems to me that the artist prioritized the opportunity to render a composition that places the four evangelists primarily in relationship to one another, rather than to text or to a different central figure. Such a priority is not set elsewhere in the programme-whether in the Plures fuisse image, with the Lamb at its axis, or even in the harmony image directly above the roundels, where the four symbols channel their attention toward the Fountain.

In their tight constellation, with Eusebian sections in the middle, the four additional symbols most closely reprise the tympanum composition at the opening of the canons (fol. $7 \mathrm{r}$ ). Here, all the evangelist symbols' attention clusters around the open book announcing the title of Canon $\mathrm{I}-$ much as all the animals' attention on fol. $6 \mathrm{v}$ focuses on the frontispiece Fountain. If the tympana images primarily visualize the idea of permutated, coordinated distinction among the gospels, the ad hoc evangelist figures on fol. 11r demonstrate a compositional focus on the unit of four.

The presence of Christ in the Soissons canons similarly taps into some fundamental points regarding how illu-

58 Stefan Trinks discusses these figures in his treatment of 'living' canon tables in this volume. 


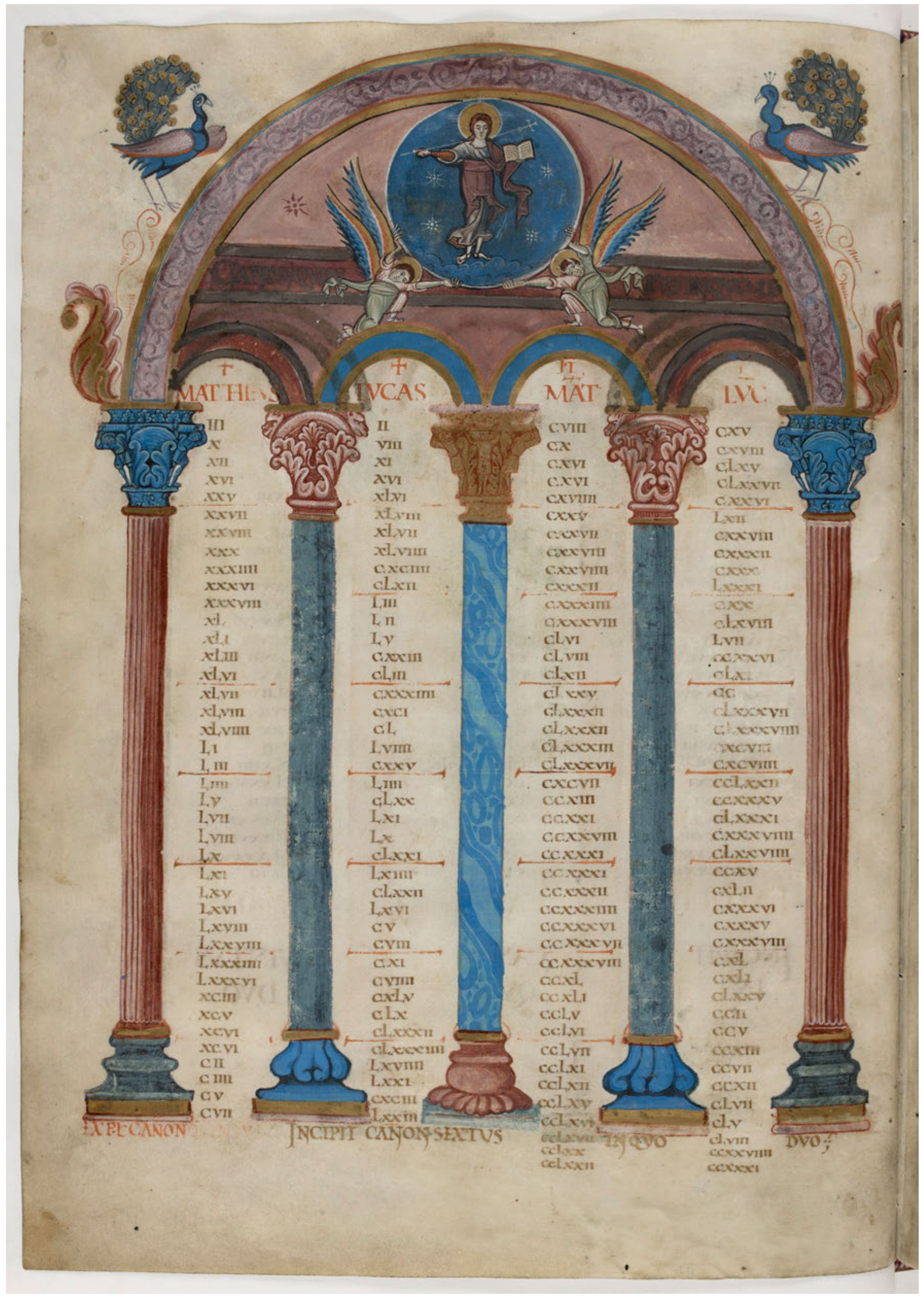

Fig. 9: Canon Tables V-VIII, Aachen (?), first quarter of the ninth century. Paris, Bibliothèque nationale de France, MS lat. 8850, fols 10v-11r. Photo: Bibliothèque nationale de France. 


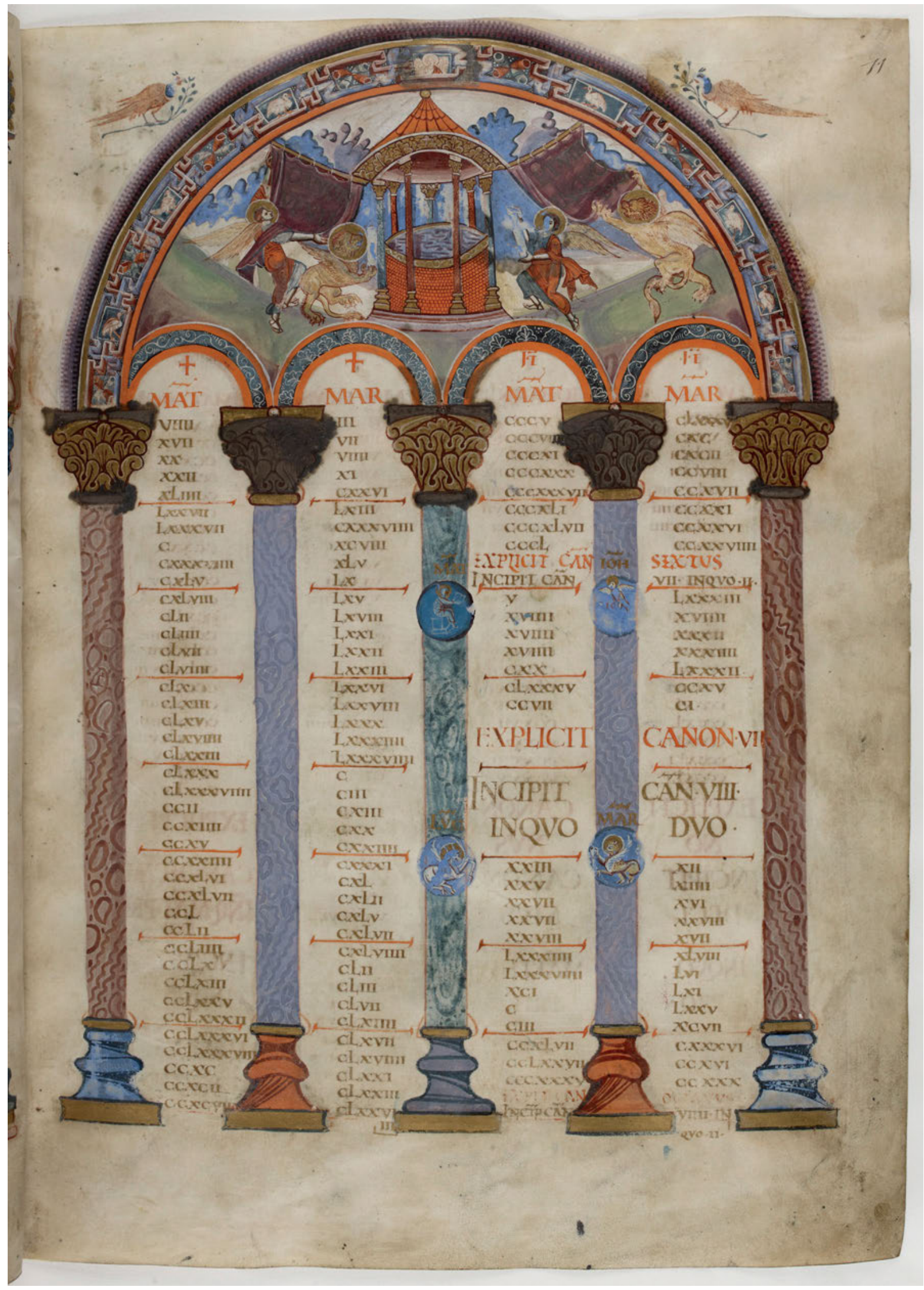




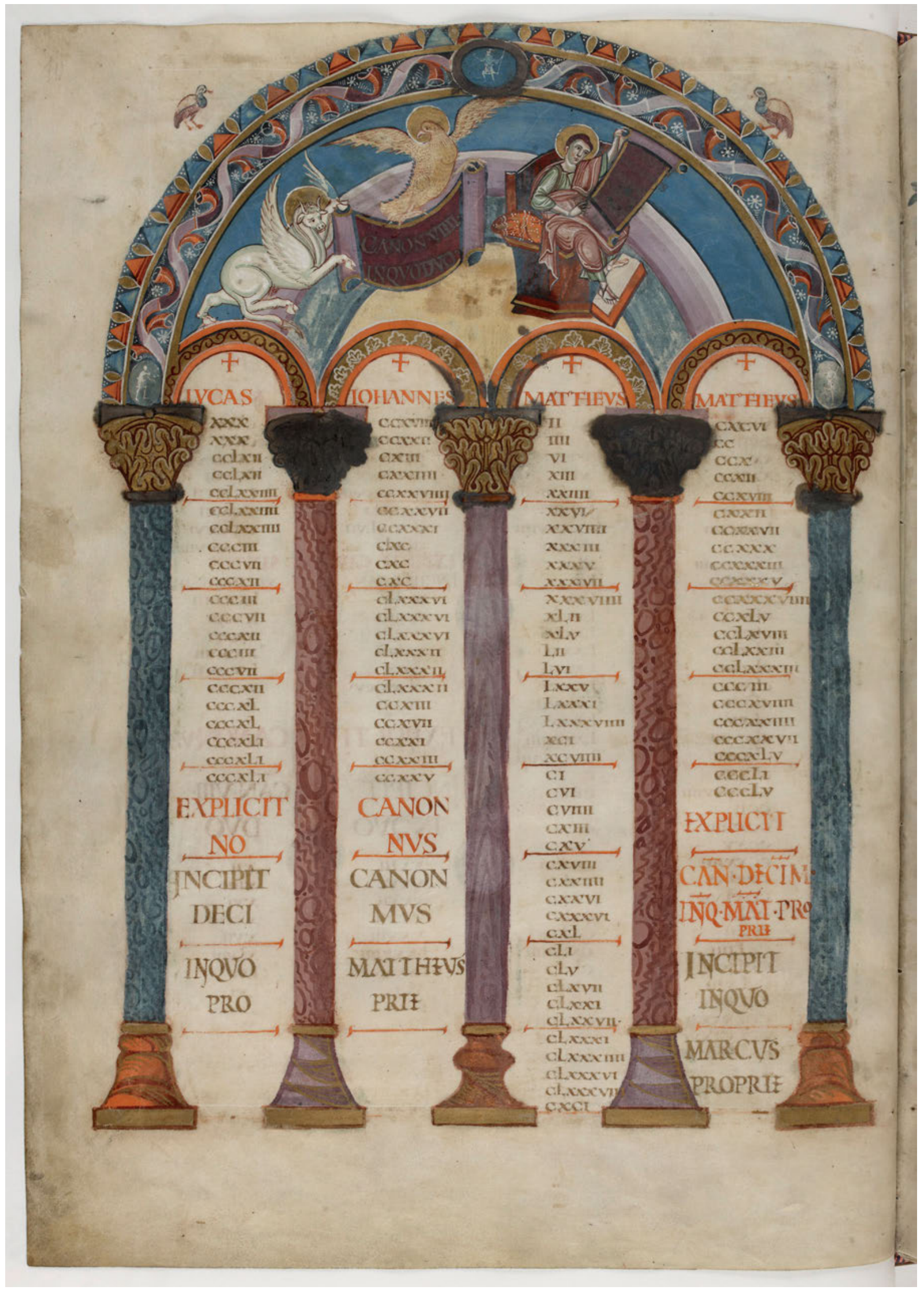

Fig. 10: Canon Tables IX-X. BnF, MS lat. 8850, fol. 11v. Photo: Bibliothèque nationale de France. 
mination can communicate a role for canon tables within a gospel manuscript. These points concern how Christ himself-the central subject of the gospel and the central presence of the gospel book-appears, relative to the text of scripture..$^{59}$ Between full-page images and figural initials, a number of possibilities emerge. I will concentrate on the effect of representing Christ in the context of canon tables, as the Soissons painter did. ${ }^{60}$

Older traditions make a place for Christ's figure in the setting of the canons (an idea taken up by some later painters, such as the Ripoll artists of Biblioteca Apostolica Vaticana, MS Vat. lat. 5729, fol. 366r). The Rabbula Gospels presents Christ as part of narrative scenes that border (and sometimes span) the space of the tables. Making the canon tables the theater for gospel scenes ties the person of Christ to the unified gospel, but also creates a play between the notion of text that is couched in the numeric system and the notion of story that is evoked by the images. The Soissons Gospels canon tables operate differently-as do the vast majority of surviving figural canon tables known to me in the early medieval Latin tradition. Here, the figure of Christ is explicitly located outside of the gospel story. This is true textually as well as visually in Underwood's reading. As Immanuel, Christ's appearance sounds a note from Isaiah-a typological feature kin to the decision to include figures like David in the Rabbula tables. Purely visually, the significant features of the composition include the figure's lack of a scenic setting and his juxtaposition with the Fountain of Life across the same opening. Lest the composition be mistaken for an Ascension scene, the two angel-evangelists holding Christ's aureole in Soissons kneel decidedly on the supporting arches of the canons. Like the plaques held by the symbols to announce the canon numbers, this detail also anchors the group as part of the representational field of the tables themselves. As Underwood observed, the figure of Christ works in concert with the scene across the opening. In any form Christ might take, his juxtaposition with the four symbols visualizes the source of their unity. With the symbols gathered specifically around the Fountain of Life, flanked by two curtains, Christ's presence across the gutter comes to function as another kind of gloss, pointing out the substance of the metaphor on the recto.

In the meaningful combination of their iconography and their format, the Soissons Gospels speak again to a point about canon illumination that is both ubiquitous and highly flexible. From the earliest surviving exam-

59 See esp. Palazzo 2010; Ganz 2017; Lentes 2009, 342-45. 60 For further reflection on images imbricated in letters and frames, see Kitzinger 2020. ples, canon table painters developed a veritable tradition of playing on the way canon tables occupy full openings as they designed figural programmes to stage the tables. Principles of permutation and progression are as elemental to the Eusebian system as is the principle of unity. The varying ways painters harnessed these ideas speak, on one front, to how the canon tables could be integrated into visual statements about the theologies or communities in which the gospel book participates. On another front, the painters' inventive approaches speak directly to their recognition of how essentially Eusebius designed his system to exercise the codex form. ${ }^{61}$

In the sixth-seventh-century 'Golden Canon Tables' held in the British Library (Additional MS 5111/1), a different member of the Church community appears on each of the surviving pages. ${ }^{62}$ Most are positioned in a roundel at the fork of two arches; one appears in the middle of the tympanum over Eusebius's Letter to Carpianus. Paul is iconographically recognizable; the others are indeterminate (although the bust above the letter seems safely designated as Peter). One cannot address the treatment of openings in this fragmentary case, but one can already cite an attention to variation as the tables progress. The sequence of the tables provides a platform to bring figures other than the evangelists into the fold of simultaneous diversity and unity that the canons represent. The sub-type of illuminated canons that Nordenfalk identified as 'apostolic' takes this theme further. ${ }^{63}$ Consistently and visibly, the openings connect a multiplicity of members in the apostolic community to the world of textual scholarship and representational exegesis couched in the canon tables.

The late tenth-century Anglo-Saxon gospel book held in Trinity College, Cambridge (MS B.10.4) offers a good example of the continued development in artists' approach both to the unit of the opening and to the progression through a canon set. ${ }^{64}$ Folios $9 r-10 r$ contain Canon I, and the decoration of the tympana proceeds according to a strict rhythm of book-matched symmetry, filled with birds, beasts, and foliage. Canon II takes up two openings that operate on similar principles with different denizens (Figs 11 and 12). Folios 10v-11r host two angels flanked by buildings. The two face towards each other across the gutter but they are not identical in attributes or posture (Fig. 11). Folios 11v-12r similarly juxtapose

61 For the apt description of Eusebius as an 'impresario of the codex', see Grafton and Williams 2008.

62 The manuscript is digitized: http://www.bl.uk/manuscripts/FullDisplay.aspx?ref=Add_MS_5111/1\&index=16 (last accessed 13/04/2020). 63 Nordenfalk 1963.

64 The manuscript is fully digitized: https://mss-cat.trin.cam.ac.uk/ viewpage.php?index=6 (last accessed 13/04/2020). 


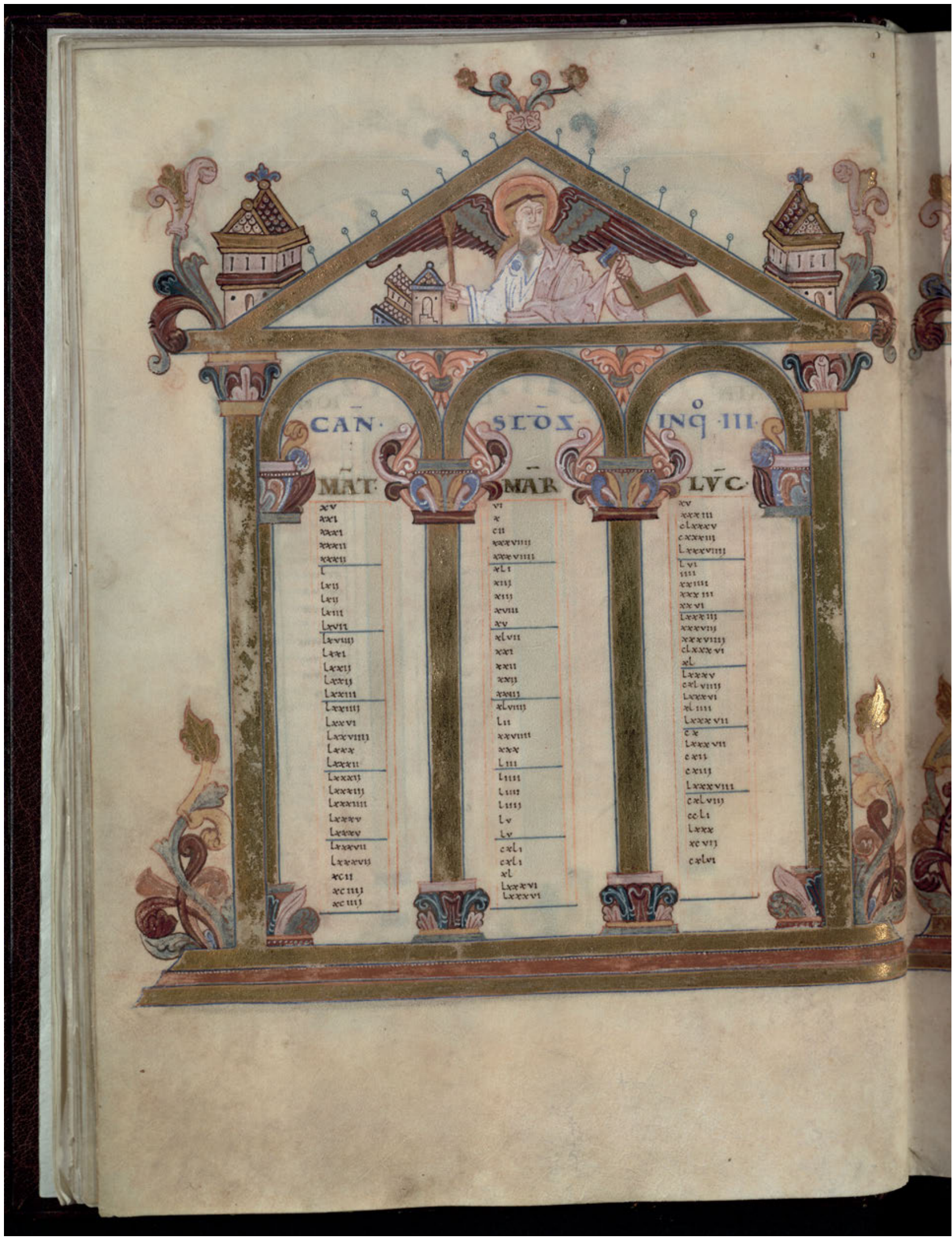

Fig. 11: Canon Table II, Canterbury (?), late tenth century. Cambridge, Trinity College Library, MS B.10.4, fols 10v-11r. Photo: Master and Fellows of Trinity College, Cambridge, by kind permission. 


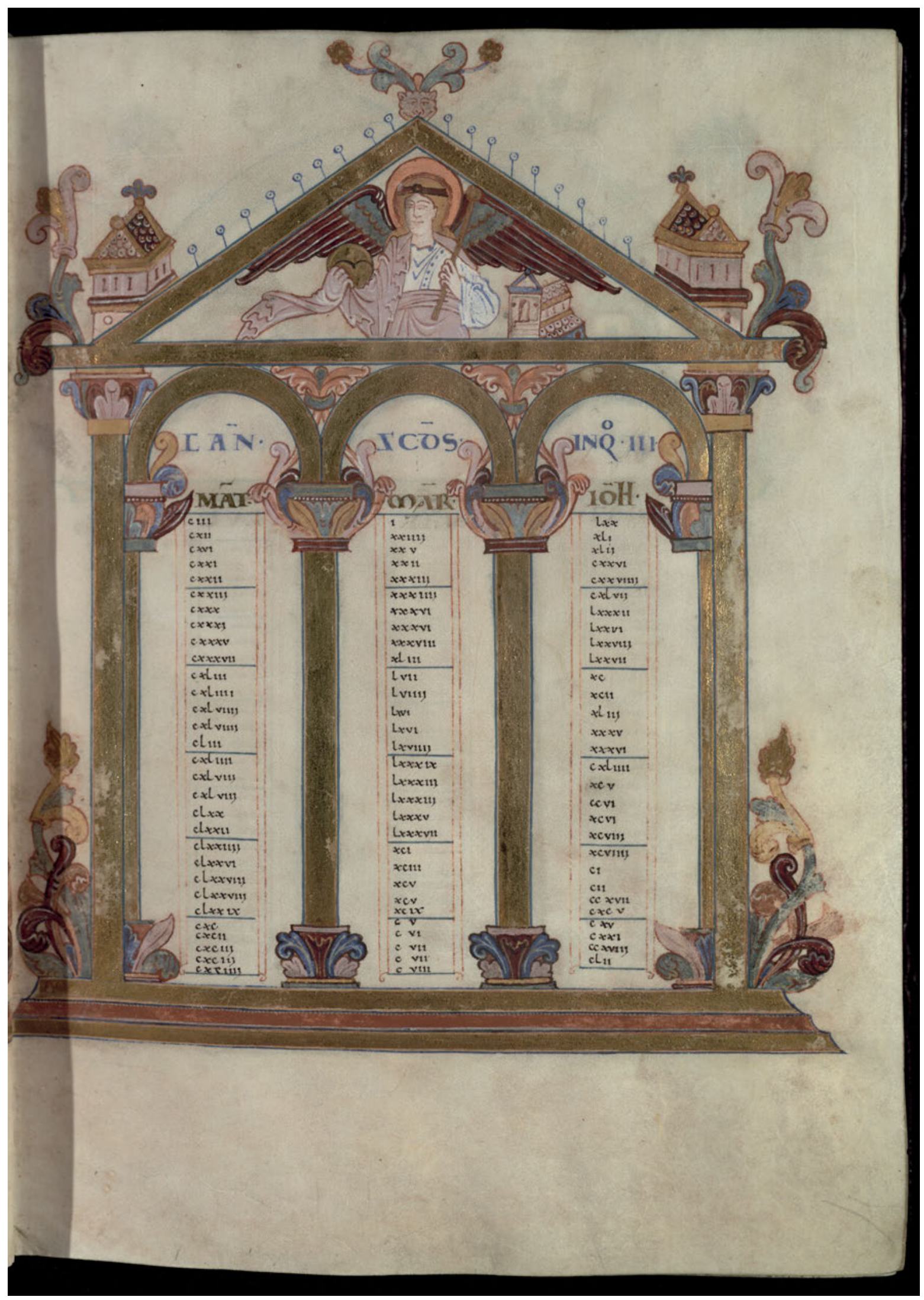




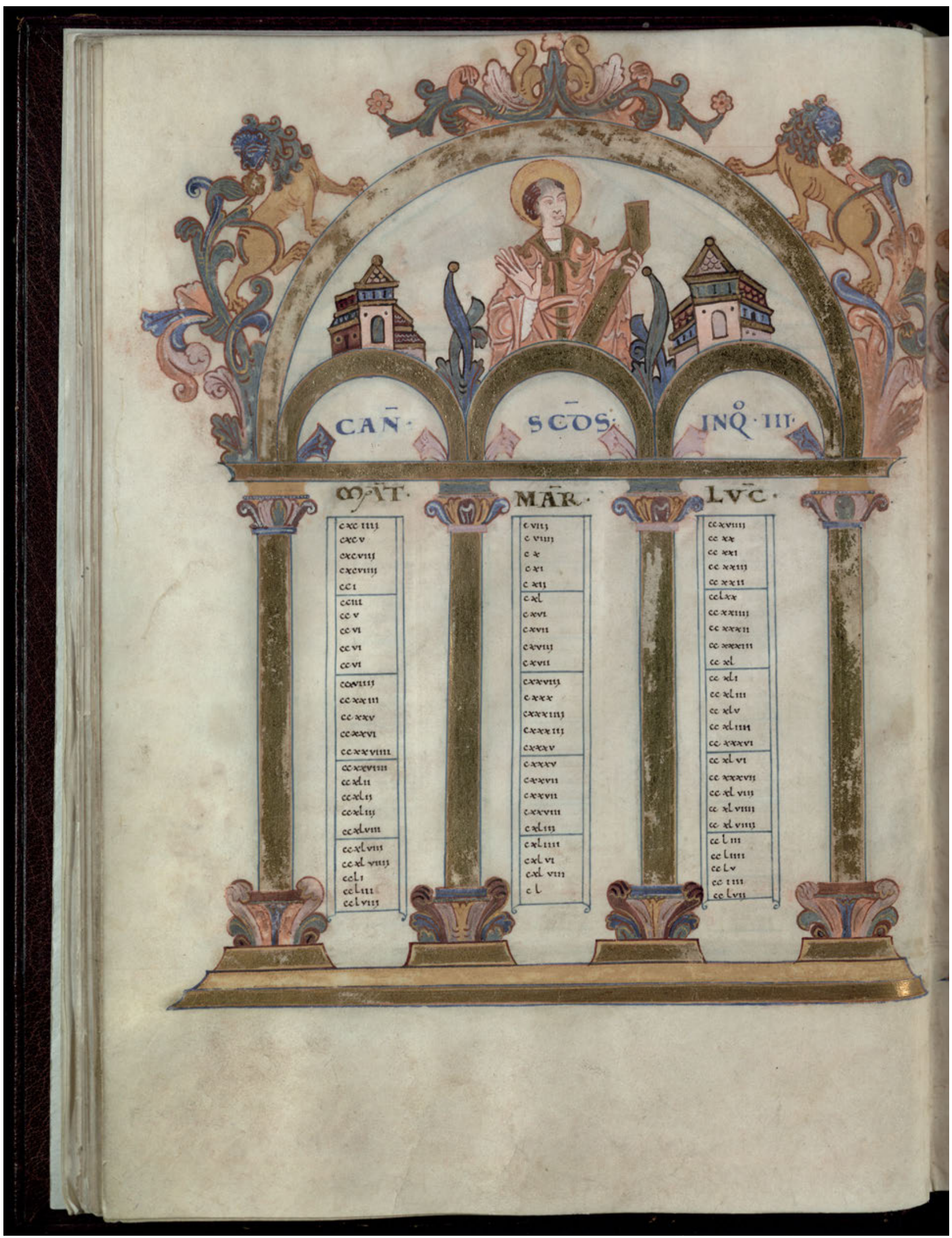

Fig. 12: Canon Table II. Trinity College, MS B.10.4, fols 11v-12r. Photo: Master and Fellows of Trinity College, Cambridge, by kind permission. 


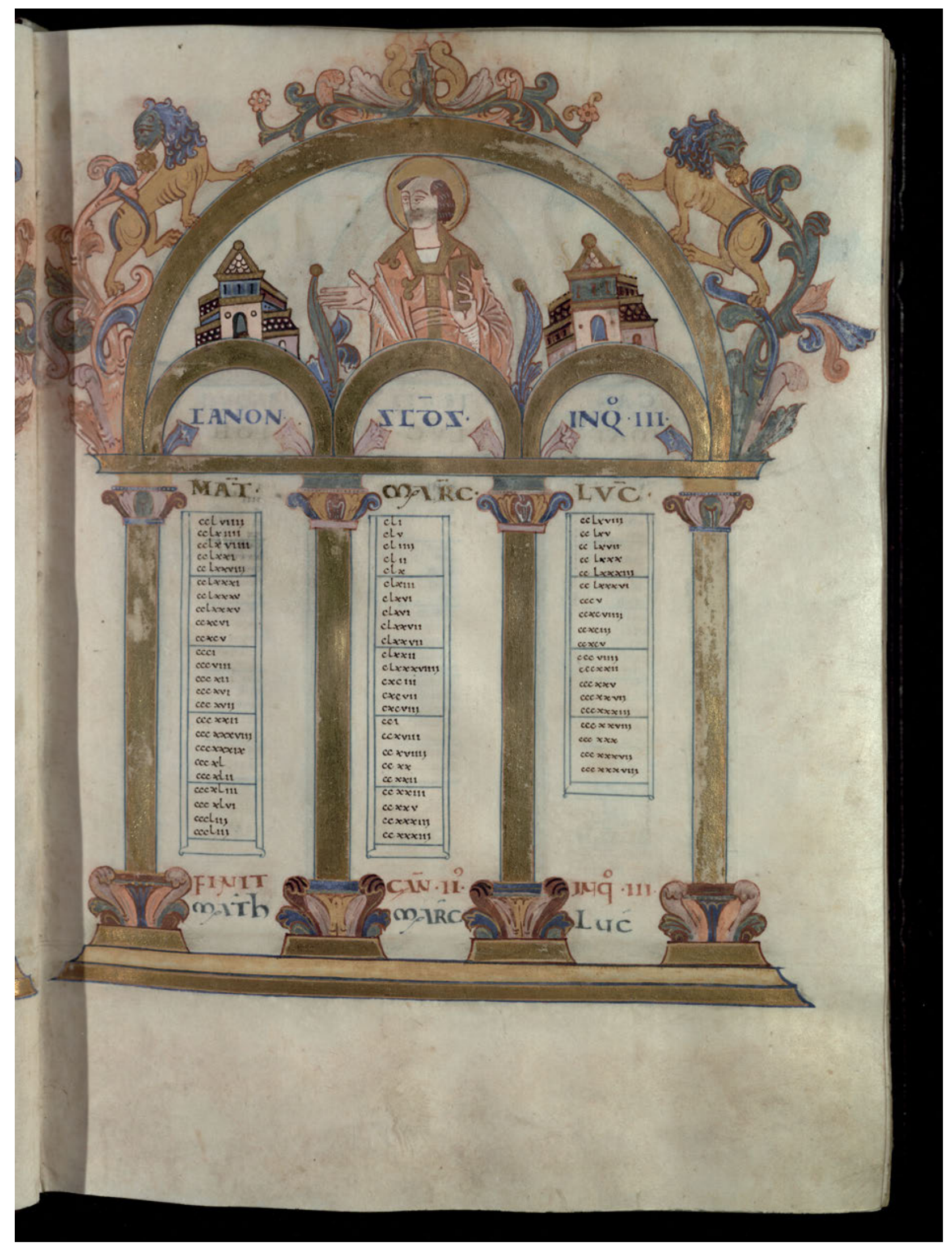




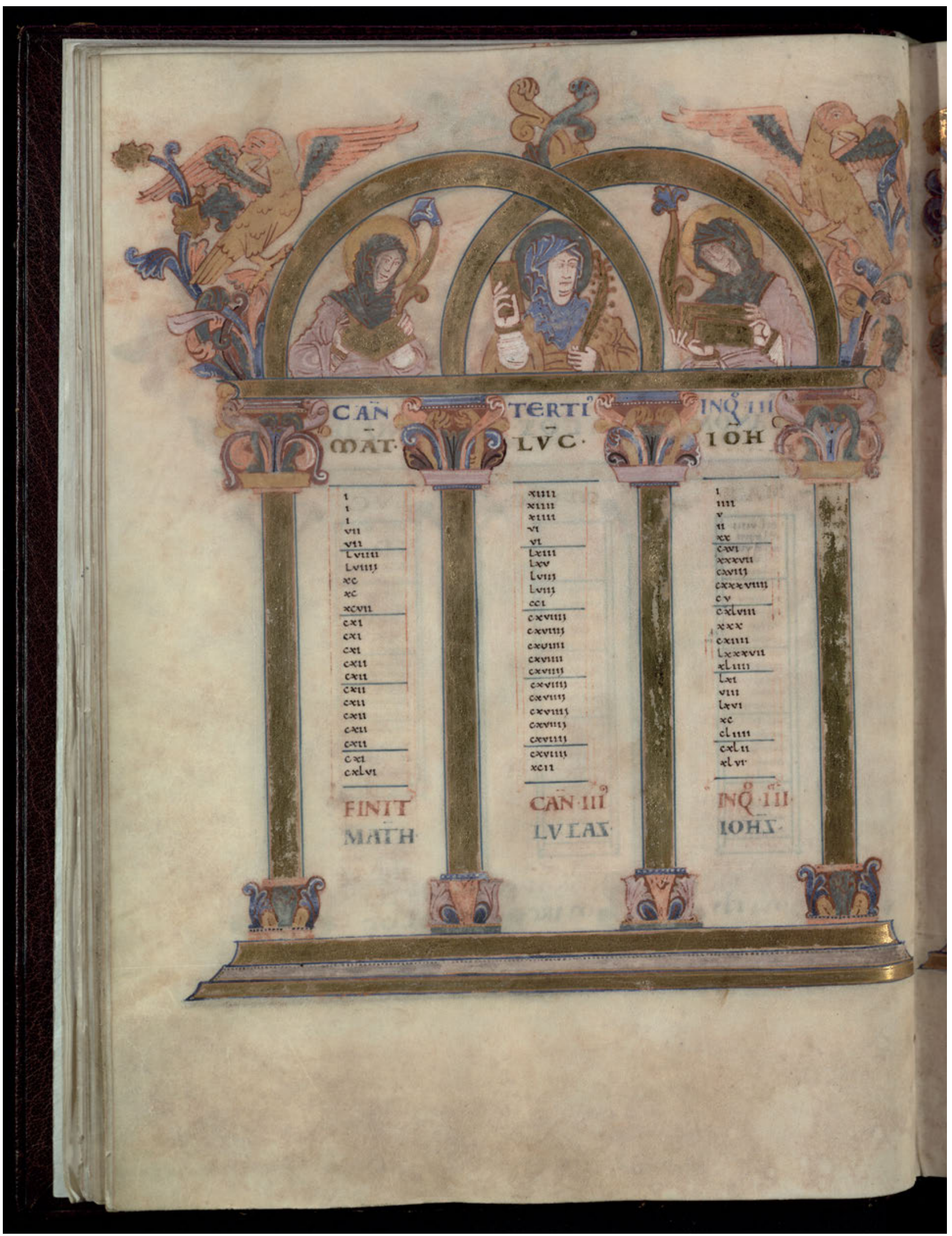

Fig. 13: Canon Tables III-IV. Trinity College, MS B.10.4, fols 12v-13r. Photo: Master and Fellows of Trinity College, Cambridge, by kind permission. 


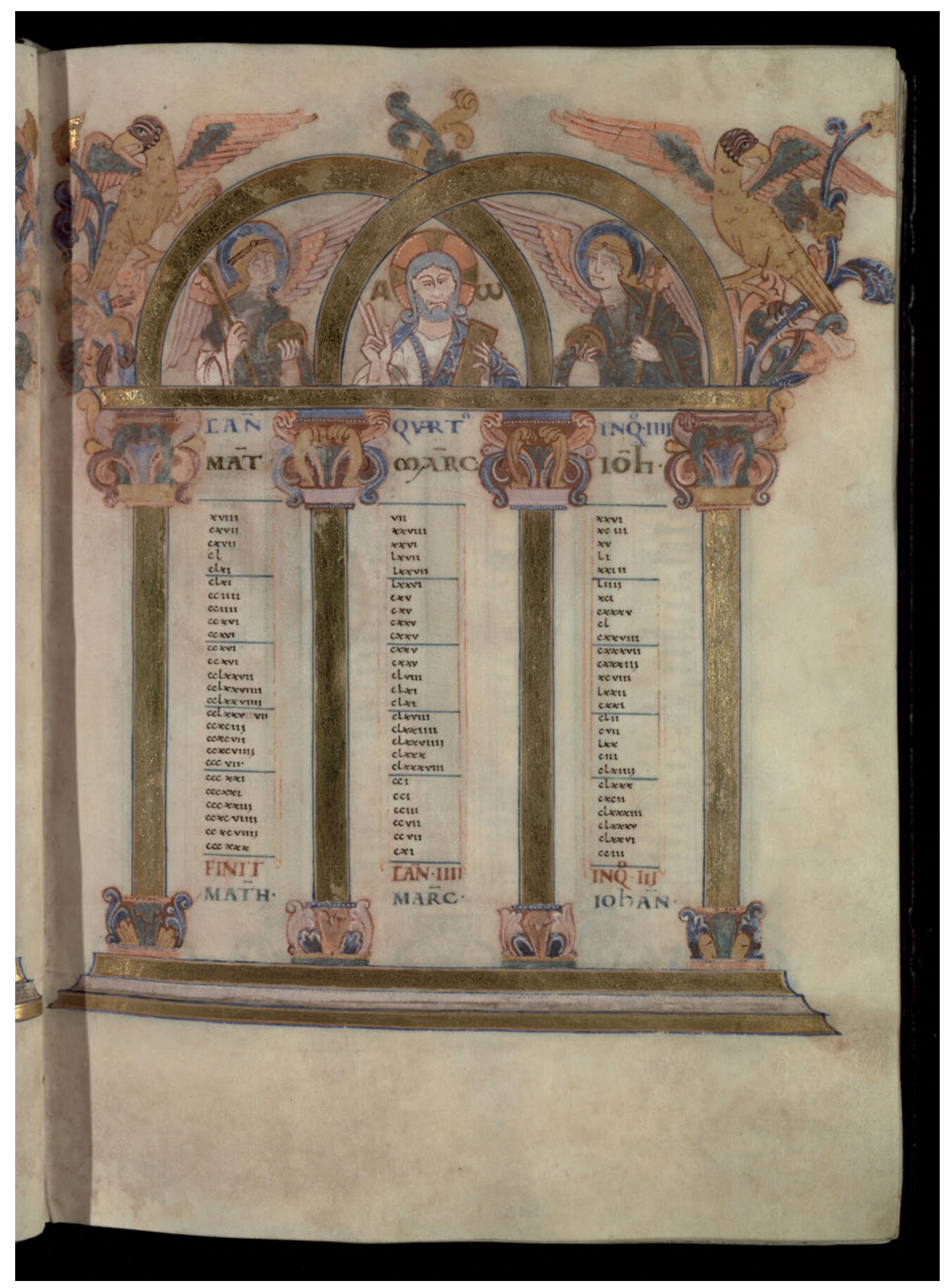




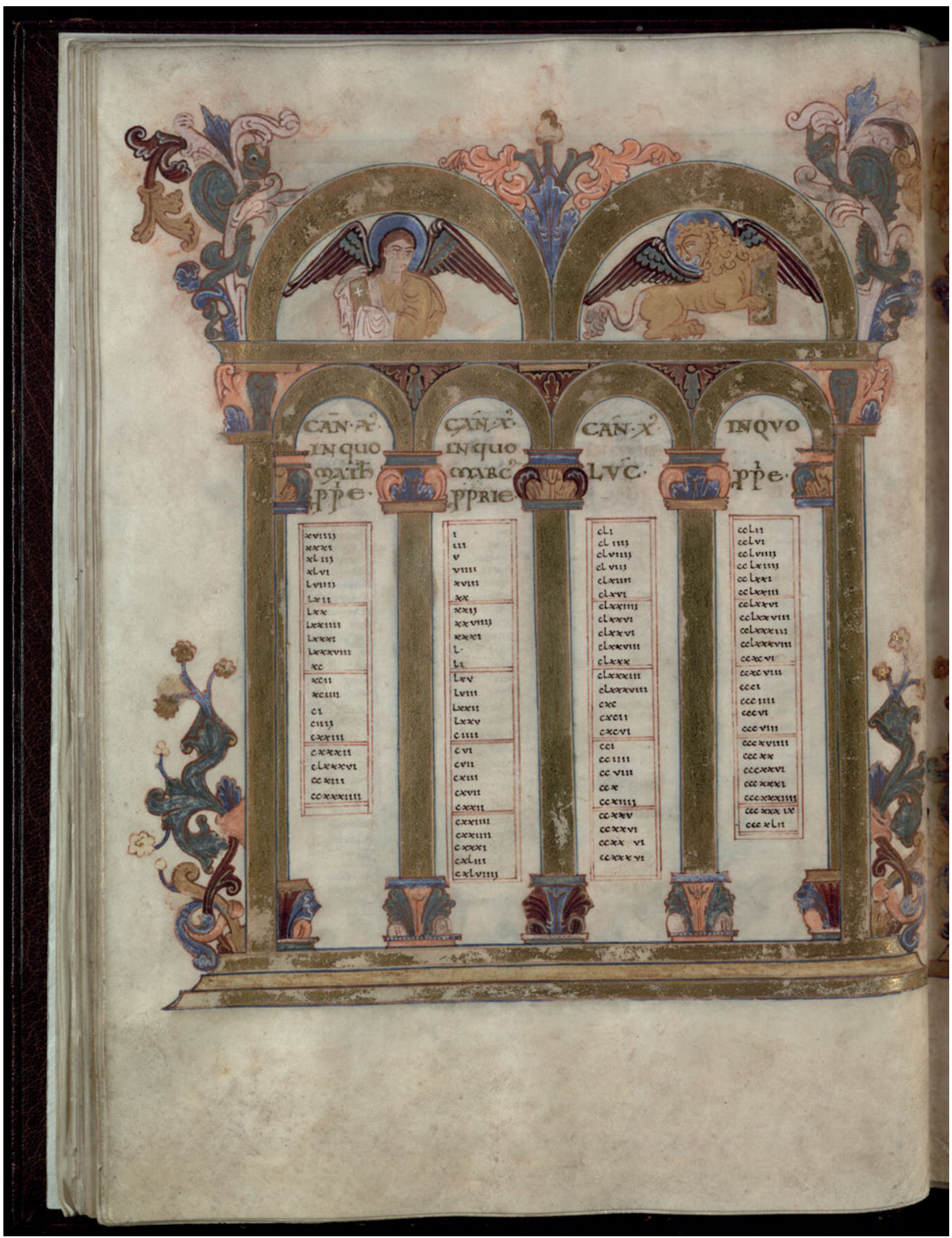

Fig. 14: Canon Table X. Trinity College, MS B.10.4, fols 15v-16r. Photo: Master and Fellows of Trinity College, Cambridge, by kind permission. 


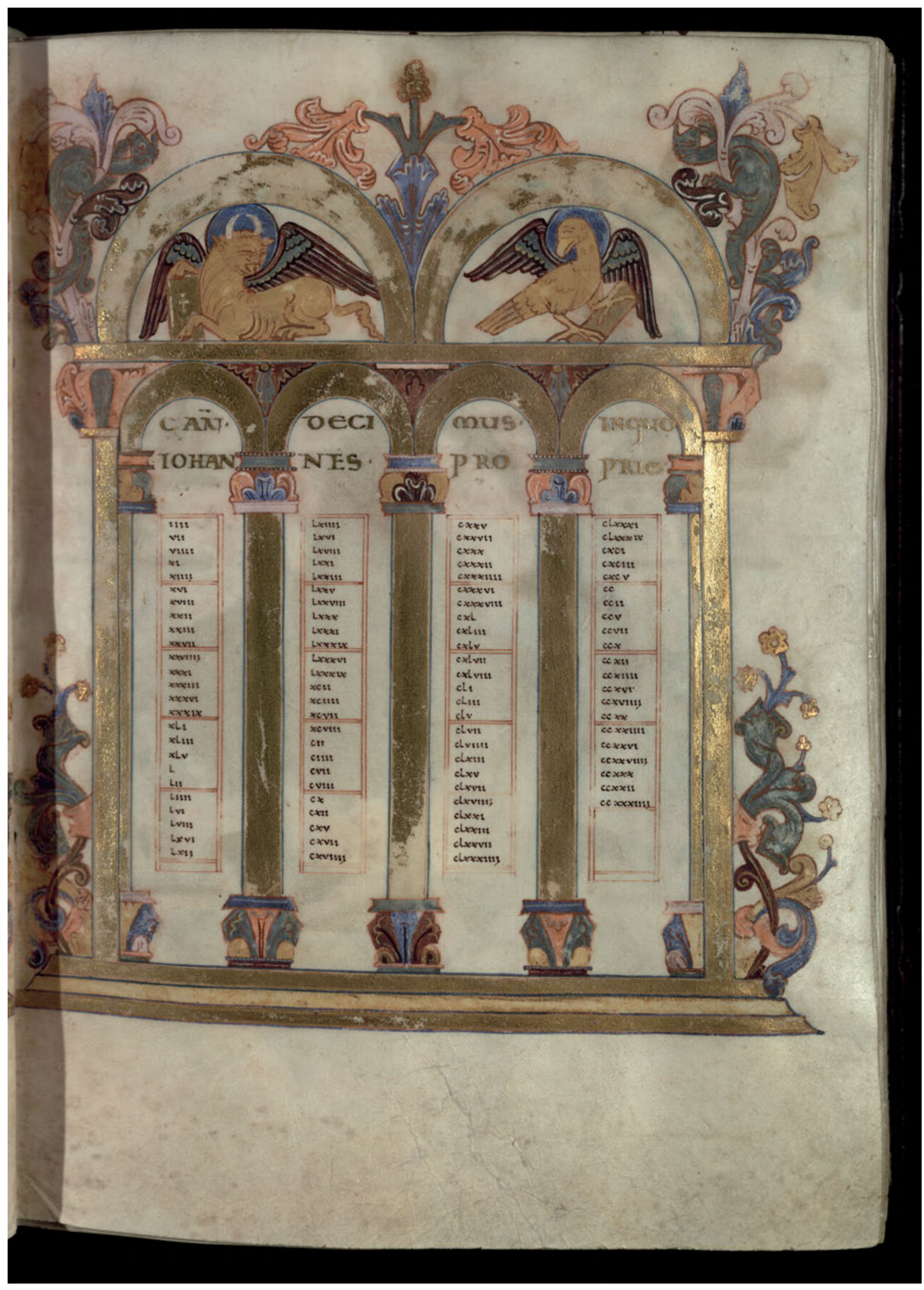




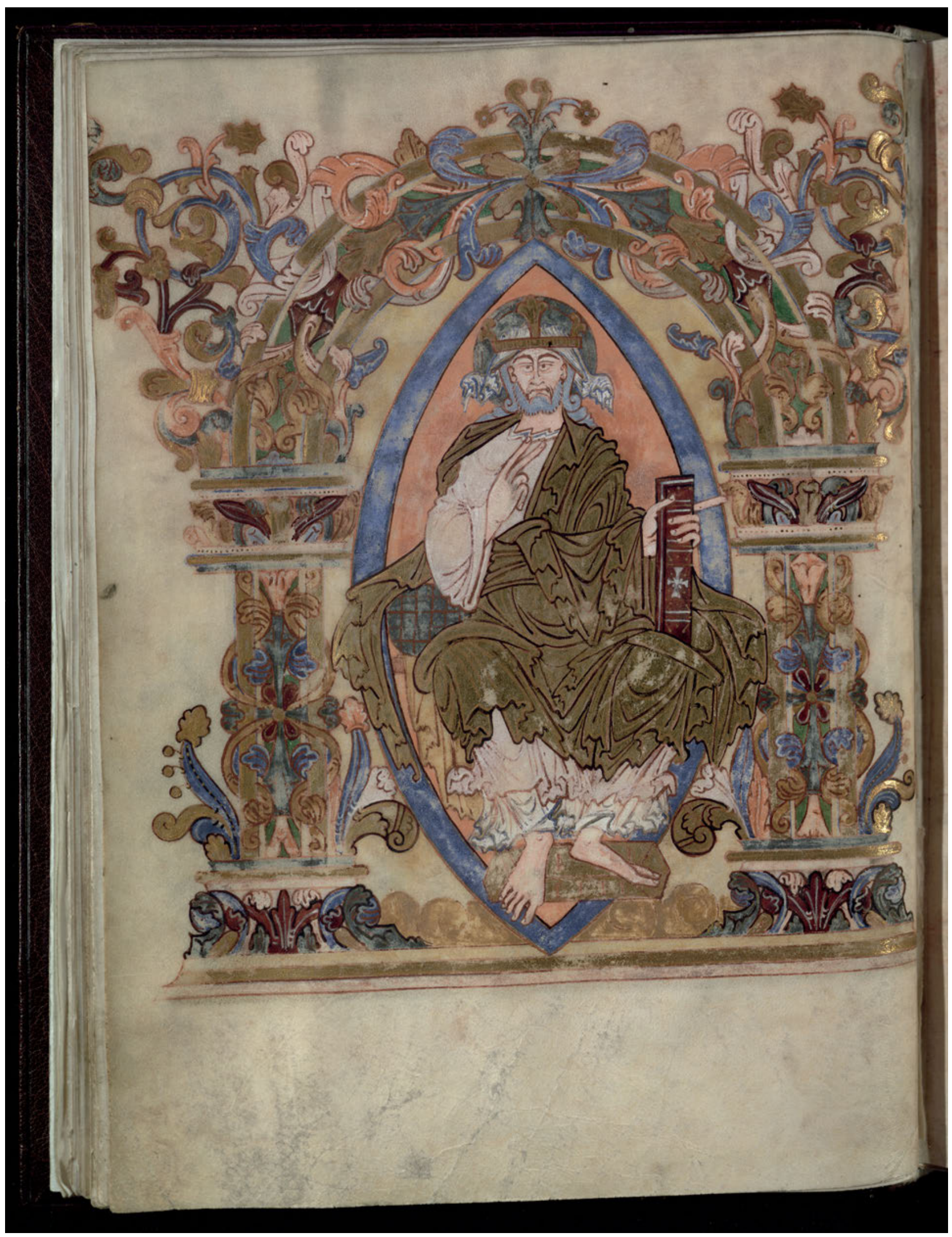

Fig. 15: Christ Enthroned and Incipit to Matthew. Trinity College, MS B.10.4, fols 16v-17r. Photo: Master and Fellows of Trinity College, Cambridge, by kind permission. 


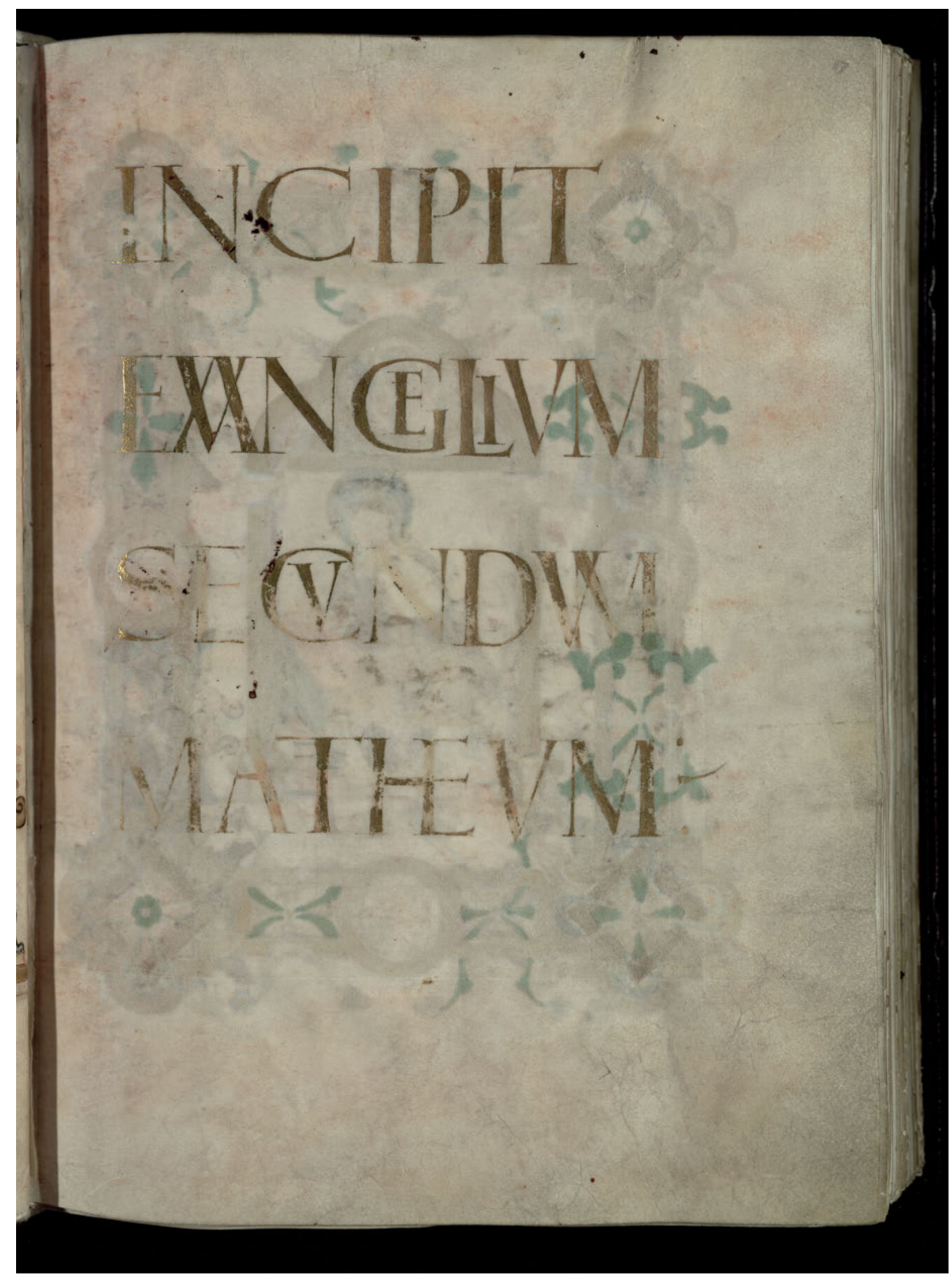


two haloed ecclesiastics, clearly in conversation with each other (Fig. 12). Canons III and IV occupy one opening, in which the variation across the gutter is greater (Fig. 13). On each of folios $12 \mathrm{v}$ and $13 \mathrm{r}$ the painter capitalized on the three spaces created by two overlapping archways to present a major central figure flanked by two others. On the verso side a female saint with book and martyr's palm looks over toward the right. Two other holy women with books accompany her, facing in toward her figure. On the recto, Christ is rendered in his judging aspect from Revelation, attended by two angels and facing outward. Canons $\mathrm{V}$ through the beginning of $\mathrm{X}$ appear on folios $13 \mathrm{v}-14 \mathrm{r}$ and revert to the ornamental model. The rest of Canon X presents the four symbols, one to an arch across folios $14 \mathrm{~V}-15 \mathrm{r}$ and therefore uncoordinated with the contents of the lists below (Fig. 14). The sequence ends on folio $15 \mathrm{v}$ with a fullpage Maiestas domini (Fig. 15).

In the Trinity Gospels' Canon II, the artist adopted a strategy that might be described as midway between the 'Beast Canon Table' and the 'Apostolic Canon Table' types. Two figures appear in conversation, reflecting the idea of balanced relationship and exchange, but they are not the evangelists. Together, they broaden the definition of the community invested in the gospels to include both earthly and heavenly ministers. In Canon III-IV, the opening again becomes the unit of a relationship, but the balance of power shifts between verso and recto sides, introducing a sense of argument and hierarchy to the choice of figures. When the four evangelists finally appear, the guiding principle of their disposition is not, as in Soissons, to key each symbol to the Eusebian sections beneath it. Rather, the four appear as a set that overrides the specifics of the tables underneath. This set exists not just in internal coherence and conversation, but in relation to the Maiestas overleaf. The conversational groups of two symbols are united in the center by the poses of Mark and Luke, which symmetrically balance each other like the peacocks of Canon I, even as their heads turn back to engage Matthew and John, who bookend the set. The culminating enthroned Christ (grey-bearded and veiled in a way that recalls the Ancient of Days from Touronian Revelation frontispieces) appears himself beneath an elaborate arch. He completes the canon tables by demonstrating the source of their unity. Much like the Immanuel in the Soissons Gospels, both here and in Canon IV, Jesus is represented as the Christ predicted in the gospels and other scriptural sources, not the one described on earth -the Christ not ministering but come again.

In the Trinity Gospels, the sense of sequence and progression first builds, but then scatters. The approach to Christ by human members of the Church up until fol. 13r seems broken off for two openings before the finale revelation of his full-length figure at the close of the tables. ${ }^{65}$ By contrast, the highly complex theological programme identified by Jane Rosenthal in the Anglo-Saxon Arenberg Gospels (c.1000) takes to an extreme the idea of fitting a steady and progressive visual argument to the specific form a codex affords the canon tables. ${ }^{66}$ In Rosenthal's account, the progressive structure of the tables is harnessed for a temporally contingent argument about the stages of history. ${ }^{67}$ Lynley Herbert's discussion of Poitiers, Bibliothèque Municipale, MS 17 in this volume indicates an earlier exercise of similar thinking (with a lighter touch). The Soissons Gospels, by contrast again, shows a regular rhythm and decorative logic punctuated by a site-specific change in the visual programme. The commonality in these disparate cases is rooted in the recognition that the form of canon tables, the form of a codex, and the content of illumination can be made to intersect in a way that defines the tables as a preface to scripture. This preface communicates ideas about the definition of that scripture-both in its content and its form as a material text.

\section{Conclusion}

An oft-noted feature of the evangelist portraits in a subset of the Carolingian 'Court School' manuscripts is that the verses visible in the authors' open books do not simply show the beginnings of their accounts, but rather steer the reader to a specific passage later in the texts. In the Harley Gospels, for instance, Matthew appears in the process of writing not 1:1 but 11:28, Venite ad me omnes qui laboratis, et onerati estis, et ego reficiam vos (London, British Library, Harley MS 2788, fol. 13v). ${ }^{68}$ Such miniature texts are not just emblematic of the written gospels; they perform work of sectioning and cross-reference that may be defined by a particular logic of selection. When interpreted-as substantively by Lieselotte Saurma-Jeltsch-that logic of selection tends to be keyed to points of Christology prominent in court circles of the early ninth century. ${ }^{69}$ This line

65 I have yet to find the explanation for placing the intercession pair across the opening for Canons III and IV. To speak to the anticipation of Judgment in Matthew, Mark, and Luke (which the portrayal of Christ clearly references), the images would need to accompany Canon II.

66 New York, The Morgan Library \& Museum, MS M.869. See Rosenthal 1974; and Rosenthal 2011.

67 Benjamin Tilghman offers a related argument about progression in the early text pages of the Book of Kells: Tilghman 2016.

68 On the phenomenon, see, e.g. Brenk 1994 and Henderson 1994.

69 Saurma-Jeltsch 1997. Saurma-Jeltsch also identifies Jerome's prefatory texts with the whole programme of the Godescalc Lectionary, and 
of argument demonstrates the power of the gospel manuscript to represent intellectual positions that are derived from interpretation of its texts. On this model, the book as a whole gains significance in its representation of theology, and demonstrates something about the role of gospel books in specific times and places as indices of people's priorities. I would suggest that an equally key function of these details is the way the painters had to think about the gospel text in order to create them in the first place. The painters treated the gospel text as something that could be excerpted, and those excerpts as something that could be visually shaped: one line or another brought to prominence such that four selections can at once be individually evaluated and create a basis for interpretation of the set in a unified way (as modern scholars do).

It is worth recalling at this point that the painters of the Augustine Gospels worked in a very similar way when they crafted the Passion grid and the Lucan evangelist portrait. The imperatives of gospel illumination were assuredly different in the varied cultural contexts of the sixth century, the ninth century, and the tenth. All the cases I have cited, however, show programmes marked by awareness that the task of materially instantiating the gospels offers the possibility visually to reflect on the resulting fusion among the text of scripture; the reading, writing, and interpretation of scripture; and the physical form of written scripture. This is a constant to take seriously.

The constellation of the elements just listed constitutes the gospel manuscript. The visual definition of that constellation itself emerges as a central concern of gospel illumination in multiple historical contexts. It is in this sense, rather than the simpler self-reflexive depiction of the evangelists as scribes, that the central subject of early medieval gospel illumination is the gospel book itself. The Augustine Gospels contains one of the most fulsome surviving examples of Christological narrative in a gospel context prior to the Ottonian revolutions on this score. ${ }^{70}$
However, the narrative is neither presented nor structured as a simple recapitulation of the story told in gospel text. Like the Prüm Gospels' Nativity sequence, the narrative is based in the redaction and cross-reference of text and context, such that its representation of the gospels is both dependent on and revelatory of the structure of the full book. In this sense, the subject of the images is not only the life of Christ; it is the transmission of that life in a particular medium and genre.

In the first section of this paper, I termed the compositional choices evident in the Augustine Gospels a 'Eusebian habit'. In the sixth century-that is, in the early years of Latin gospel illumination as we know it-the question of what bookmakers' engagement with Eusebius specifically had to do with the development of ideas in gospel book-making is different (and perhaps more pressing) than that same question in later contexts, although the reform movements of the Carolingians and the Anglo-Saxons are surely not irrelevant to the problem. ${ }^{71}$ Direct engagement with Eusebius may well be a provable cause and driver of compositional choices throughout gospel manuscripts in certain cases, depending on their historical context. More broadly, though, I propose that the idea of a Eusebian habit remains useful because it helps to excavate the effects of observable compositional choices in many areas of the illuminated gospel tradition. Looking across time at Late Antique and early medieval gospel books and thinking with Eusebius about how to handle text does not, I would say, primarily reveal durable patterns of interpretation for the textual content of gospel books-these are highly context-specific. Instead, thinking with Eusebius reveals patterns by which gospel books were consistently characterized as a type of manuscript in which text, its apparatus, its genre, and its medium all work togetherfour in one. the prologues with the historical vignettes of the Soissons Gospels. 70 For highly relevant discussion of the relationship between figural illumination and canon tables in an Ottonian context, see Winterer 2008.
71 I thank Anne-Orange Poilpré for a memorable discussion on the functions of gospel narrative in reform contexts. She reflects on Carolingian fusions of narrative form, content, and medium in Poilpré 2018. Further on the representation of books connected to Anglo-Saxon reforms, see Adam S. Cohen's contribution to Denoël, Poilpré and Shimahara 2018. 


\section{References}

Beissel, Stephan (1907), Entstehung der Perikopen des römischen Meßbuches: zur Geschichte der Evangelienbücher in der ersten Hälfte des Mittelalters, Freiburg i.B.: Herder.

Binski, Paul and Stella Panayotova (eds) (2005), The Cambridge Illuminations: Ten Centuries of Book Production in the Medieval West, London: Harvey Miller.

Breay, Claire and Joanna Story (eds) (2018), Anglo-Saxon Kingdoms: Art, Word, War. London, The British Library.

Brenk, Beat (1994), 'Schriftlichkeit und Bildlichkeit in der Hofschule Karls des Grossen,' Testo e immagine nell'alto Medioevo: 15-21 Aprile 1993, Settimane di studio del Centro Italiano di Studi sull'Alto Medioevo, 41/2, Spoleto: Centro Italiano di Studi sull'Alto Medioevo, 631-682.

Brown, Michelle P., Ildar H. Garipzanov, and Benjamin C. Tilghman (eds) (2017), Graphic Devices and the Early Decorated Book, Woodbridge: The Boydell Press.

Budny, Mildred (1997), Insular, Anglo-Saxon, and Early Anglo-Norman Manuscript Art at Corpus Christi College, Cambridge, Kalamazoo, MI: Medieval Institute Publications.

Coogan, Jeremiah (2017), 'Mapping the Fourfold Gospel: Textual Geography in the Eusebian Apparatus', Journal of Early Christian Studies, 25/3, 337-357.

Crawford, Matthew R. (2015), 'Ammonius of Alexandria, Eusebius of Caesaria and the Origins of Gospel Scholarship', New Testament Studies, 61, 1-29.

Darby, Peter (2017), 'The Codex Amiatinus Maiestas Domini and the Gospel Prefaces of Jerome', Speculum, 92/2, 343-371.

De Hamel, Christopher (2017), Meetings with Remarkable Manuscripts: Twelve Journeys into the Medieval World, New York: Penguin Press.

Denoël, Charlotte (2018), 'La parole révélée: essai sûr la symbolique visuelle du livre dans les livres d'évangiles de l'Époque de Charlemagne', in Große and Sot (eds) (2018), 477-505.

Denoël, Charlotte, Anne-Orange Poilpré and Sumi Shimahara (eds) (2018), Imago libri. Représentations carolingiennes du livre, Turnhout: Brepols.

Dombrowski, Damian (2019), 'Die erste Seite des Evangeliars aus Saint-Médard in Soissons. Zeit- und Reichsbewusstsein in der karolingischen Kunst', in Susanne Ehrich and Andrea Worm (eds), Geschichte vom Ende her denken: Endzeitentwürfe und ihre Historisierung im Mittelalter, Regensburg: Schnell \& Steiner, 21-46.

Farr, Carol (1997), The Book of Kells: Its Function and Audience, London: British Library; Toronto and Buffalo: University of Toronto Press.

Gameson, Richard (ed.) (2017), The Lindisfarne Gospels: New Perspectives, Library of the Written Word, 57, The Manuscript World, 9, Leiden, Boston: Brill.

Ganz, David (2017), 'The Cross on the Book: Diagram, Ornament, Materiality', in Brown/Garipzanov/Tilghman (eds) 2017, 243-264.

Grafton, Anthony and Megan Williams (2008), Christianity and the Transformation of the Book: Origin, Eusebius, and the Library of Caesarea, Cambridge, MA: Harvard University Press/ Belknap.
Große, Rolf and Michel Sot (eds) (2018), Charlemagne: les temps, les espaces, les hommes. Construction et déconstruction d'un règne, Turnhout: Brepols.

Henderson, George (1993-94), “"The Foxes have Holes,” Once Again', Wiener Jahrbuch für Kunstgeschichte, 46-47: 245-254.

Henderson, George (1994), 'Emulation and Invention in Carolingian Art', in Rosamond McKitterick (ed), Carolingian Culture: Emulation and Innovation, Cambridge: Cambridge University Press, 248-273.

Henderson, George (1999), Vision and Image in Early Christian England, Cambridge: Cambridge University Press.

Holländer, Hans (1969), Kunst des frühen Mittelalters, Belser Stilgeschichte, 5, Stuttgart: Belser.

James, Montague Rhodes (1936-37), 'Four Leaves of an English Psalter', Walpole Society, 25, 1-23.

Kauffmann, C. M. (2003), Biblical Imagery in Medieval England, 700-1550, London: Harvey Miller.

Kitzinger, Beatrice (2013), 'Troyes, Bibliothèque municipale, 960. Approaches to Ninth-Tenth Century Breton Gospel Illumination', Rivista di Storia della Miniatura, 17, 29-42.

Kitzinger, Beatrice (2017), 'Graphic and Figural Representation in Touronian Gospel Illumination', in Brown/Garipzanov/Tilghman (eds) 2017, 179-202.

Kitzinger, Beatrice (2018), 'Representing the Gospels Beyond the Carolingian Center', in Denoël/Poilpré/Shimahara (eds) 2018, 151-161.

Kitzinger, Beatrice (2019), The Cross, the Gospels, and the Work of Art in the Carolingian Age, New York: Cambridge University Press.

Kitzinger, Beatrice (2020), 'Framing the Gospels, c. 1000: Iconicity, Textuality, and Knowledge', in Marcia Kupfer, Adam Cohen, J.H. Chajes and Andrea Worm (eds), The Visualization of Knowledge in Medieval and Early Modern Europe, Turnhout: Brepols.

Koehler, Wilhelm (1958), Die karolingischen Miniaturen, II: Die Hofschule Karls des Grossen, Berlin: Deutscher Verein für Kunstwissenschaft.

Larsen, Matthew D. C. (2018), Gospels Before the Book, New York: Oxford University Press.

Lavin, Marilyn Aronberg (1990), The Place of Narrative: Mural Decoration in Italian Churches, 431-1600, Chicago and London: University of Chicago Press.

Lentes, Thomas (2009), 'A maioribus tradita: Zur Kommunikation zwischen Mythos und Ritus im mittelalterlichen Messkommentar', in Peter Strohschneider (ed.), Literarische und religiöse Kommunikation in Mittelalter und früher Neuzeit, Berlin, New York: Walter de Gruyter, 324-370.

Lewine, Carol F. (1979), 'Vulpes Fossa Habent or the Miracle of the Bent Woman in the Gospels of St Augustine, Corpus Christi College, Cambridge, MS 286', The Art Bulletin, 56, 489-504.

Lowden, John (1999), 'The Beginning of Biblical Illustration,' in John Williams (ed), Imaging the Early Medieval Bible, University Park: Pennsylvania State University Press, 9-60.

Meyvaert, Paul (1979), 'Bede and the Church Paintings at Wearmouth-Jarrow', Anglo-Saxon England, 8, 63-77.

Mullins, Elizabeth (2001), 'The Insular Reception of the Eusebian Canon Tables: Exegesis and Iconography', PhD Diss., University College Cork. 
Mütherich, Florentine, with Katharina Bierbrauer, Fabrizio Crivello and Matthias Exner (2009), Die karolingischen Miniaturen, VII: Die frankosächsische Schule, Wiesbaden: Dr. Ludwig Reichert Verlag.

Netzer, Nancy (1994a), 'The Origin of the Beast Canon Tables Reconsidered', in Felicity O'Mahony (ed), The Book of Kells: Proceedings of a Conference at Trinity College, Dublin, 6-9 September 1992, Aldershot and Hants [England]; Brookfield, VT: published for Trinity College Library, Dublin by Scolar Press, 322-332.

Netzer, Nancy (1994b), Cultural Interplay in the Eighth Century: The Trier Gospels and the Making of a Scriptorium at Echternach, Cambridge Studies in Paleography and Codicology, 3, Cambridge: Cambridge University Press.

Nordenfalk, Carl (1963), 'The Apostolic Canon Tables', Gazette des Beaux-Arts, 62, 17-34.

O’Driscoll, Joshua (2019), 'Shaping Tradition: The Use of the Carolingian Past in a Tenth-Century Gospel Book in the Morgan Library (PML MS.319)', in Beatrice Kitzinger and Joshua O'Driscoll (eds), After the Carolingians: Redefining Manuscript Illumination in the 10-11 $1^{\text {th }}$ Centuries, Berlin: De Gruyter, 213-244.

O’Loughlin, Thomas (2010), 'Harmonizing the Truth: Eusebius and the Problem of the Four Gospels', Traditio, 65, 1-29.

O'Loughlin, Thomas (2017), 'The Eusebian Apparatus in the Lindisfarne Gospels: Ailerán's Kanon euangeliorum as a Lens for its Appreciation', in Gameson (ed.) 2017, 96-111.

O'Reilly, Jennifer (1998), 'Patristic and Insular Traditions of the Evangelists: Exegesis and Iconography of the Four-Symbols Page', in Anna Maria Luiselli Fadda and Éamonn Ó Carragáin (eds), Le Isole britanniche e Roma in età romanobarbarica, Rome: Herder, 49-94.

Palazzo, Éric (2010), 'Le 'livre-corps’ à l'époque carolingienne et son rôle dans la liturgie de la messe et sa théologie', Quaestiones Medii Aevi Novae, 15, 31-63.

Poilpré, Anne-Orange (2013), 'Illustrer la vie du Christ dans un manuscrit de l'Antiquité tardive: le cas des évangiles de saint Augustin', in Chrystèle Blondeau et al. (eds), Ars auro gemmisque prior: mélanges en hommage à Jean-Pierre Caillet, Zagreb: International Research Centre for Late Antiquity and the Middle Ages, 131-138.

Poilpré, Anne-Orange (2018), 'Représenter la vie du Christ sous le règne de Charlemagne', in Große/Sot (eds) 2018, 507-527.

Pulliam, Heather (2017), 'Painting by Numbers: The Art of the Canon Tables', in Gameson (ed.) 2017, 112-133.

Reudenbach, Bruno (2009), 'Der Codex als heiliger Raum: Überlegungen zur Bildausstattung früher Evangelienbücher', in Stephan Müller, Lieselotte E. Saurma-Jeltsch and Peter Strohschneider (eds), Codex und Raum, Wolfenbütteler Mittelalter-Studien, 21, Wiesbaden: Harrassowitz, 59-84.

Reudenbach, Bruno (2018), 'Books for Liturgical Reading? Remarks on the Structure and Function of Early Medieval Gospel Books', in David Ganz and Barbara Schellewald (eds), Clothing Sacred Scriptures: Book Art and Book Religion in Christian, Islamic, and Jewish Cultures, Berlin: De Gruyter, 261-272.
Rosenthal, Jane E. (1974), 'The Historiated Canon Tables of the Arenberg Gospels', PhD Diss., Columbia University.

Rosenthal, Jane E. (2011), 'The Image in the Arenberg Gospels of Christ Beginning to Be "What He Was Not"', in Colum Hourihane (ed.), Insular and Anglo-Saxon Art and Thought in the Early Middle Ages, Princeton: The Index of Christian Art; University Park, PA: Pennsylvania State University Press, 229-246.

Saurma-Jeltsch, Lieselotte (1997), 'Das Bild in der Worttheologie Karls des Großen: zur Christologie in karolingischen Miniaturen,' in Rainer Berndt (ed.), Das Frankfurter Konzil von 794: Kristallisationspunkt karolingischer Kultur: Akten zweier Symposien (vom 23. bis 27. Februar und vom 13. bis 15. Oktober 1994), II: Kultur und Theologie, Mainz: Selbstverlag der Gesellschaft für Mittelrheinische Kirchengeschichte, 635-675.

Tilghman, Ben C. (2011), 'The Shape of the Word: Extralinguistic Meaning in Insular Display Lettering', Word and Image, 27/3, 292-308.

Tilghman, Benjamin C. (2016), 'Ornament and Incarnation in Insular Art', Gesta, 55/2, 157-177.

Tronzo, William (2001), 'The Shape of Narrative: A Problem in the Mural Decoration of Early Medieval Rome', in Roma nell'Alto Medioevo, Settimane di Studio del Centro Italiano di Studi sull'Alto Medioevo, 48/1, Spoleto: Presso la sede del Centro, 457-487.

Underwood, Paul (1950), 'The Fountain of Life in Manuscripts of the Gospels', Dumbarton Oaks Papers, 5, 43-138.

Walker, Robert (1948), 'Illustrations to the Priscillian Prologues in the Gospel Manuscripts of the Carolingian Ada School', The Art Bulletin, 30/1, 1-10.

Watson, Francis and Sarah Parkhouse (eds) (2018), Connecting Gospels: Beyond the Canonical/Non-canonical Divide, Oxford: Oxford University Press.

Willson, Justin (2020), 'Reading with the Evangelists: Portrait, Gesture, and Interpretation in the Byzantine Gospel Book', Studies in Iconography, 41, 67-103

Winterer, Christoph (2008), 'Das Wolfenbütteler Evangeliar mit den Federzeichnungen. Ikonographische Vielfalt und Dialogdarstellungen im ottonischen Corvey,' in Patrizia Carmassi (ed.), Präsenz und Verwendung der Heiligen Schrift im christlichen Frühmittelalter, Wiesbaden: Harrassowitz, 373-404.

Wormald, Francis (1954), The Miniatures in the Gospels of St. Augustine, Cambridge: Cambridge University Press.

Wormald, Francis (1977), An Early Breton Gospel Book: A Ninth-Century Manuscript from the Collection of H.L. BradferLawrence, ed. J.J.G. Alexander, Cambridge: The Roxburghe Club. 


\section{Appendix}

\section{The codicology of quires containing or missing images, CCC 286}

\section{Evaluative description}

The manuscript was rebound at the British Museum in 1948-49, and the leaves rest in paper guards. Wormald and De Hamel each reckoned twenty-two missing leaves at the beginning of the codex, based on the generally regular quaternions that make up the manuscript, but there are exceptions to the quaternion rule. The larger structure of the Matthean section, which likely included the evangelist's prologue, the canon tables and possibly the general prefaces as well, is completely unknown. However, the surviving material here and at Mark and John already testifies to the fact that no quire structure containing illumination worked in exactly the same way. All the text in the quires surrounding the gospel junctures is continuous, with the exception of the missing leaf noted below in Luke.

The surviving Lucan illumination is fully integral to a quaternion (Quire 18 in the present manuscript). The quire is not complete: the final leaf of text, which should have been conjoint with fol. 124, is missing; a stub appears between fols 130 and 131. Distinct folia house the painted pages: the Passion (fol. 125r, whose verso is blank) was probably originally conjoint with fol. 130, where the beginning of Luke's text occupies the recto and continuous text occupies the verso. The portrait (fol. 129v) is conjoint with the prologue text (fol. 126r/v). The recto of the portrait was ruled for text (the end of the capitulae); the prickings show through on the painted side but the ruling was light enough to accommodate the image on one side of the leaf. Some additional rulings were added to guide the draftsperson. Two blank pages (fol. 124v and fol. 125v) frame the unruled Passion. If this is the verifiable pattern of distribution for illumination, it is worth remarking that the surviving evidence for every other site of illumination diverges from it.

The Liber Generationis (fol. 3r) begins Quire 3 in the present manuscript (originally Quire 4, according to the medieval quire marks that appear through fol. 91 and peri- odically afterward). The gospel begins on a recto with the offset of Matthew's portrait page. The fragmentary Quire 2 contains Matthew's capitula list from the end of Chapter 12, and ends with a blank leaf (fol. $2 \mathrm{v}$ ). The portrait must have appeared on the verso of a now-missing leaf (to leave the offset on fol. 3r). The bookmakers may have left a full empty opening after the present fol. $2 \mathrm{v}$, but it is also imaginable that more content appeared on the recto of the leaf presenting the portrait on the verso (the lack of any offset on fol. $2 \mathrm{v}$ complicates this possibility), or that several missing pages distributed additional painting.

The quire containing the beginning of Mark (present Quire 12; medieval Quire 13) is the only quinion in the manuscript, occupying fols $75-83$. The portrait appeared on the verso of a missing leaf between fol. 77 and fol. 78 . Similar alternate scenarios to Matthew present themselves here as well. The blank page on fol. 74v, ending Quire 11, which now houses the tenth-century will of Ealhburg, might have been foreseen for another image in the same spot as the Passion, relative to the texts: between one gospel's explicit and the prologue to the next. Fol. 74r is pricked and lightly ruled; fol. $74 \mathrm{v}$ was not ruled separately. The recto of the missing leaf mid-quire could in theory have housed another image, facing the originally blank fol. 77v.

Before John, Quire 28 (fols 203-205) is exceptionally short as a quire of 3 , although its textual contents are complete; fols 204-205 are conjoint and the stub of fol. 203 appears after fol. 205v. The generously spaced fol. 205v contains Luke's explicit and, following John's general incipit, the only surviving prologue incipit in the manuscript. As announced, John's prologue appears directly on fol. 206r. The structure suggests that the portrait, whose offset appears on fol. 206r, either could have occupied a singleton or, perhaps more likely, the other half of fol. 203. Similarly, a short Quire 36 completes the text of John with continuous text. The offset of a narrative grid appears on fol. $265 \mathrm{v}$, suggesting that the missing leaf most likely was a singleton, or the recto of a new quire containing extra-scriptural material (such as the Capitulare evangeliorum). It is also possible that the narrative grid was displaced at some point, if it was a singleton and moved from Matthew or Mark to the end of John. 

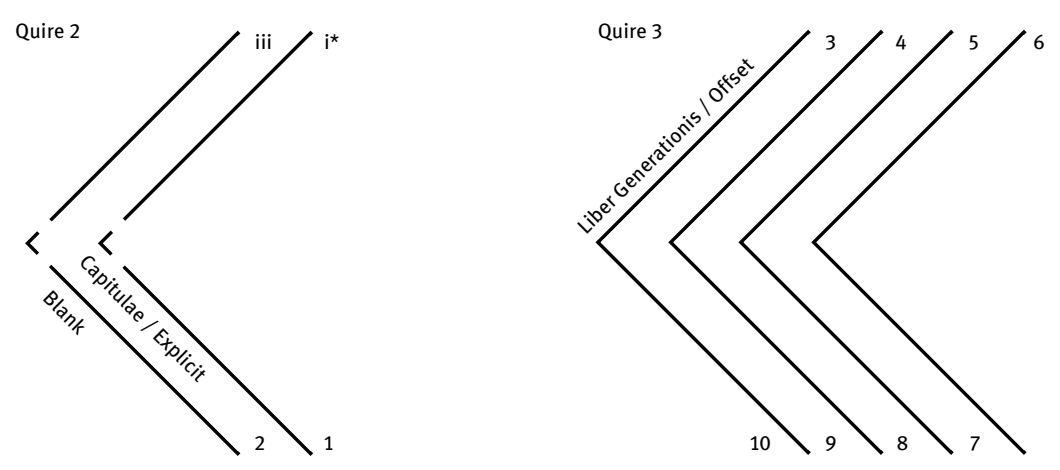

\section{Matthew}
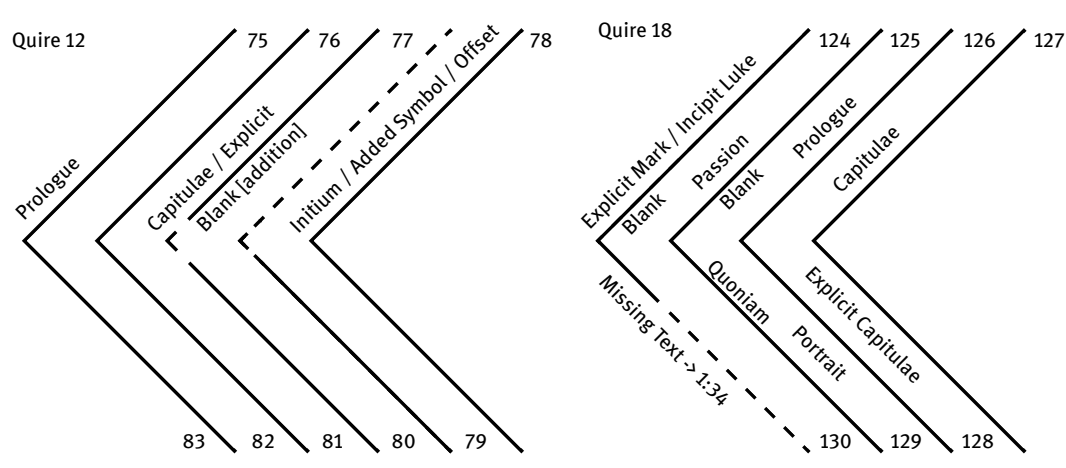

Mark

Luke
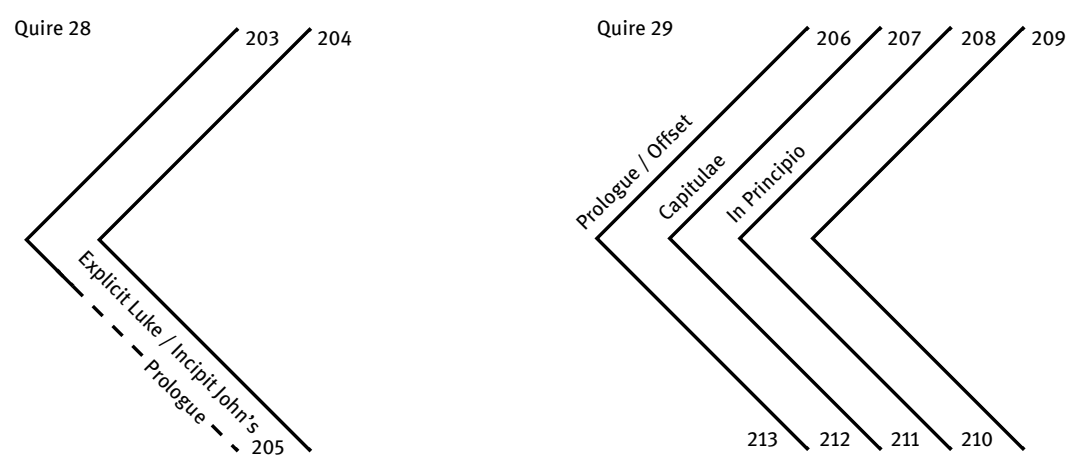

John

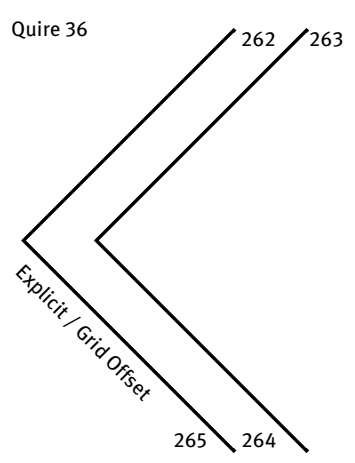

Diagram prepared in collaboration with Dr Anne McLaughlin (The Parker Library, Corpus Christi College, Cambridge), with recourse to a working chart drawn by Dr Mildred Budny (Research Group on Manuscript Evidence, Princeton). Quire numbering follows the modern collation. Drawing: author, 2019; setting: Astrid Kajsa Nylander, 2020. 
